\title{
A maior empresa que nunca um príncipe cristão teve nas mãos: conquistar e conservar territórios no Índico nos tempos de Maquiavel ${ }^{I}$
}

\author{
Ângela Barreto Xavier[1]
}

\begin{abstract}
Resumo
Quais conexões se podem estabelecer entre o pensamento teórico de Maquiavel em torno da conquista e conservação de territórios e a prática de Afonso de Albuquerque, nos territórios do Índico, plasmada numa intensa correspondência trocada com D. Manuel I? Esse é o problema ao qual se procura dar resposta neste ensaio, no qual se recorre a uma perspectiva transnacional das dinâmicas políticas e intelectuais da época moderna. Esse enfoque permite identificar a existência de uma tessitura cultural comum às elites políticas do sul da Europa quinhentista, que ajuda a explicar a existência de interessantes continuidades entre essas duas figuras políticas da Europa de Quinhentos. Ao mesmo tempo, suas diferentes biografias e contextos de ação - o de Maquiavel, essencialmente italiano, e o de Albuquerque, português, africano e asiático ajudam a explicar algumas das diferentes soluções políticas que se podem encontrar na escrita de ambos.
\end{abstract}

Palavras-chave: Maquiavel; Afonso de Albuquerque; império português.

La empresa más grande que jamás tuvo un príncipe Cristiano en las manos: conquistar y mantener a los territorios en el Océano Índico en tiempos de Maquiavelo

\section{Resumen}

¿Qué conexiones se pueden establecer entre el pensamiento teórico de Maquiavelo en torno a la conquista y el mantenimiento de territorios y la práctica de Afonso de Albuquerque en los territorios de la India, que se traslada en una intensa correspondencia con D. Manuel I? Ese es el problema que se enfrenta en este ensayo. Utilizamos una perspectiva transnacional de las dinámicas políticas e intelectuales de la era moderna. El enfoque nos permite identificar la existencia de un contexto cultural común a la elite política del siglo XVI en el sur de Europa, lo que ayuda a explicar la existencia de continuidades interesantes entre esas dos figuras políticas europeas de esa época. Al mismo tiempo, sus diferentes biografías y contextos de acción - de Maquiavelo esencialmente italianos, y de Albuquerque, portugueses, africanos y asiáticos ayudan a explicar algunas de las diferentes soluciones políticas que se pueden encontrar en la escritura de ambos.

Palabras clave: Maquiavelo; Afonso de Albuquerque; el imperio portugués.

The biggest enterprise a Christian prince ever had in his hands: to conquer and conserve territories in the Indian Ocean in the times of Machiavelli

\section{Abstract}

Can we establish connections between the theoretical thinking of Machiavelli about the conquest and conservation of territories and the actions of Afonso de Albuquerque in the territories of the Indian Ocean (described in an intense correspondence between him and the king D. Manuel I of Portugal)? In this essay, I try to answer this question by adopting a transnational perspective of the political and intellectual dynamics of the early-modern period. This approach enables me to identify the common cultural background among the political elites from Southern Europe in the $16^{\text {th }}$ century, and helps to explain the existence of interesting continuities between Albuquerque and Machiavelli. Simultaneously, their different biographies and contexts of action - Machiavelli's were mainly Italian, while Albuquerque's were Portuguese, African and Asiatic - contribute to explain some of the differences in the political solutions proposed by them in their writings.

Keywords: Machiavelli; Afonso de Albuquerque; Portuguese empire.

La plus grande entreprise qu'un prince chrétien a dejá eu: conquérir et conserver des territoires dans l'océan Indien au temps de Machiavel

Résumé

Quelles connexions peuvent être établies entre la pensée théorique de Machiavel sur la conquête et rétention des territoires et les activités d'Afonso de Albuquerque dans les territoires de l'océan Indien, et une intense correspondance avec D. Manuel I? Nous nous efforçons de donner une réponse a ce problème dans cet article, en utilisant une perspective transnationale de les dynamiques politiques et intellectuelles de l'époque moderne. Cet approche nous permet d'identifier l'existence d'une trame culturelle commun aux élites politiques de l'Europe du sud du XVIème siècle, pour expliquer l'existence d'intéressants continuités entre ces deux personnalités politiques. En même temps, leur différences biographiques et de contextes - celui de Machiavel, essentiellement italien; et celui d'Albuquerque, portugais, africain et asiatique — aident à expliquer quelques solutions politiques qui peuvent se trouver dans leur textes.

Mots clés: Machiavel; Afonso de Albuquerque; empire portugais.

Artigo recebido em 17 de março de 2014 e aprovado para publicação em 22 de maio de 2014.

[1] Instituto de Ciências Sociais da Universidade de Lisboa - Lisboa - Portugal. E-mail: angela.xavier@ics.ulisboa.pt

'Este estudo realizou-se no âmbito dos projetos O governo dos outros: imaginários políticos no império português, financiado pela Fundação para a Ciência e Tecnologia (Portugal), PTDC/HIS/104640/2008, e do projeto Terras além dos mares: direitos de propriedade no império português moderno, financiado pela mesma entidade, PTDC/HIS-HIS/113654/2009. Agradeço muito a generosidade da Rita Marquilhas, que me disponibilizou bibliografia essencial para o enquadramento da correspondência de Albuquerque. 


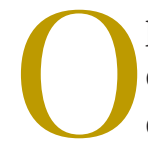

presente trabalho analisa as conexões entre as ideias de conquista e de conservação política de Afonso de Albuquerque (c. 1453-1515), tal como estas se plasmam na sua correspondência entre 1507 e 1515, com as que Maquiavel (1469-1527) desenvolve em Il principe (1513) nos I discorsi sopra le Decade de Tito Livio (1519) e no menos conhecido tratado Dell'arte della guerra (1521). ${ }^{2}$

Os textos de Maquiavel, é sabido, ocupam um lugar central nas bibliotecas e enciclopédias ocidentais sobre esses dois temas e Maquiavel é considerado por muitos como o fundador da "ciência política moderna". ${ }^{3}$ Por seu turno, as conquistas de Albuquerque também têm, muito embora em menor escala, um caráter paradigmático, pois a Albuquerque são atribuídos alguns dos maiores feitos militares - feitos fundacionais - do império português. Esses feitos mereceram-lhe os epítetos de César do Oriente ou Alexandre Magno e também explicam que tenha sido iconizado na memória coletiva portuguesa por meio de estátuas, praças, jardins e ruas, nomes atribuídos a escolas, fragatas e aviões, pinturas, gravuras, inúmeros livros e até mesmo centenários. A fama de Albuquerque transcende, ainda, o universo exclusivamente português. O orientalista britânico Morse Stevens, numa biografia que lhe dedica em 1892, escreveu que "Affonso de Albuquerque was the first European since Alexander the Great who dreamed of establishing an empire in India, or rather in Asia, governed from Europe". Esse topos, presente em textos anteriores, continua a alimentar a literatura que tem Albuquerque como objeto, apesar de este não ter sido reconhecido como fazendo parte do panteão dos grandes estrategas. ${ }^{4}$

Não é o objetivo de reconhecer esse epíteto que motiva as próximas páginas. $\mathrm{O}$ que aqui se propõe é explorar os paralelos e as possíveis articulações que se podem estabelecer entre essas duas figuras - uma mais atreita à ação militar (Albuquerque), enquanto a outra (Maquiavel), não a desconhecendo, foi mais vocacionada para a política de gabinete e para a reflexividade política. ${ }^{5}$ Esses paralelos não foram ainda explorados pelos interessados

\footnotetext{
2Mikael Hörnquist, "Machiavelli's military project and the art of war", In: John M. Najemy (org.), The Cambridge companion to Machiavelli, Cambridge, Cambridge University Press, 2010, p. 112-127.

3É impossível citar, aqui, a vastíssima bibliografia que existe sobre Maquiavel, pelo que reencaminho o leitor para um site onde poderá encontrar uma lista muito completa de referências. Hyper Machiavellism. Disponível em: <http://www.hypermachiavellism.net/?q=en/materiali/bibliografie>. Acesso em: 26 de maio de 2014.

${ }^{4}$ Ver, a esse propósito, Fernando Gomes Pedrosa, Afonso de Albuquerque e a arte da guerra, Cascais, Câmara Municipal de Cascais, 1998. O mesmo tipo de adjetivação pode ser encontrada, ainda hoje, em vários sites da internet, contribuindo, dessa forma, para a preservação desse senso comum. Ver Morse Stevens, Albuquerque, Oxford, Clarendon Press, 1982, prefácio. A mesma ideia surge em Frederick Charles Danvers, The Portuguese in India, London, W. H. Allen, 1894, e Richard Stephen Whiteway, The rise of Portuguese power in India: 14971550, New Delhi, Asian Educational Services, 2007 [1899]. São algumas as biografias disponíveis sobre Afonso de Albuquerque, entre as quais, a mais fiável continua a ser a de Geneviéve Bouchon, Albuquerque: leão dos mares da Ásia, Lisboa, Quetzal, 2000. Ver também Edgar Pestage, Afonso de Albuquerque, Governor of India: his life, conquests and administration, Watford, Voss \& Michael, 1929; António Baião, Afonso de Albuquerque, Lisboa, Livraria Ferin, 1913; Costa Brochado, Afonso de Albuquerque, Lisboa, Portugália, 1943; Elaine Sanceau, Afonso de Albuquerque: o sonho da India, Lisboa, Livraria Civilização, 1953. Todas elas, porém, concentram-se no período "indiano" de Albuquerque, descurando, por falta de fontes, a maior parte da sua vida. ${ }^{5}$ Robert Black, "Machiavelli in the Chancery", In: John M. Najemy (org.), The Cambridge companion to Machiavelli, Cambridge, Cambridge University Press, 2010, p. 31-47.
} 
no estudo da cultura política da época moderna. Ainda atraída por grandes textos e grandes autores, a história das ideias políticas não considerou atores que, como Albuquerque, não deixaram nenhum testamento político sistemático da sua ação (às suas cartas não lhe é reconhecido, ainda, esse estatuto). ${ }^{6}$ Por seu turno, a história política de Quinhentos tem preferido a ação política em palcos europeus e mediterrânicos, raramente conectando estes com os palcos "ultramarinos" - como se estes fossem histórias separadas. Para isso, contribuiu, evidentemente, a hegemonia da "história nacional", a qual tendeu a relegar a "história imperial ultramarina" para um campo disciplinar distinto (talvez porque a "história imperial" de algumas potências historiográficas, como a França e a Alemanha, foi essencialmente europeia). Também essa longa hegemonia, hoje felizmente ultrapassada, não favoreceu este tipo de estudos. ${ }^{7}$

Existem conexões entre o pensamento político de Afonso de Albuquerque e o de Maquiavel relativamente a esses temas? Caso elas se verifiquem, como podem ser explicadas? Apontam para a existência de um lastro cultural mediterrânico na cultura política de Quinhentos, de raiz cristã e humanista, com aspirações imperialistas onipresentes, abrangendo, entre outras entidades políticas, Florença (Itália) e Portugal ${ }^{8}$

Essas dimensões/questões serão exploradas a partir da análise da correspondência escrita por Afonso de Albuquerque ao rei D. Manuel I e a outros membros da Corte portuguesa quinhentista. ${ }^{9}$ Uma das principais práticas sociais da cultura escrita moderna, ${ }^{10}$ as 116 cartas redigidas por Afonso de Albuquerque entre 1507 e 1515 a partir do Índico constituem um corpo documental muito rico e de volume diversificado: encontram-se cartas muito extensas, quase minitratados, como a de $1^{\circ}$ de abril de 1512 , cartas médias e cartas

\footnotetext{
${ }^{6}$ er, além dos trabalhos antes citados, João Rocha Pinto, "O vento, o ferro e a muralha - a construção do império asiático no século XVI", In: Vitorino Magalhães Godinho, Estudos e ensaios: em homenagem a Vitorino Magalhães Godinho, Lisboa, Sá da Costa, 1998.

${ }^{7} \mathrm{O}$ mesmo tipo de reflexão está presente em Francisco Bethencourt, "The political correspondence of Albuquerque and Cortes", In: __ Florika Egmond (org.), Correspondence and cultural exchange in Europe: 1400-1700, Cambridge, Cambridge University Press, 2007, e sustenta o interessante livro de Kate Lowe (org.), Cultural links between Portugal and Italy in the Renaissance, New York, Oxford University Press, 2000. Ver, ainda, Alfonso Borrero Cabal; Luisa d’Arienzo, Toscana e Portogallo. Miscellanea storica nel $650^{\circ}$ aniversario dello Studio Generale di Pisa. Studi del Departimento di Scienze della Politica dell'Universita di Pisa, Pisa, ETS, 1994.

¿Sobre as aspirações imperialistas de Florença e a sua presença em Maquiavel, ver Mikael Hörnquist, Machiavelli and empire, Cambridge, Cambridge University Press, 2004. Todavia, este estudo incide, apenas, sobre o espaço europeu.

'Ver Cartas de Afonso de Albuquerque seguidas de documentos que as elucidam, ed. Raymundo António Bulhão Pato, vol. 1, Lisboa, Academia Real das Sciencias de Lisboa, 1884. A correspondência de Albuquerque tem sido objecto de traduções em língua inglesa. Ver Walter de Gray Birch, The commentaries of the Great Alfonso Dalboquerque, Second viceroy of India, New York. B. Franklin, 1963; John Villiers; Thomas Foster Earle (orgs.), Albuquerque, Caesar of the East: selected texts, Warminster, Aris \& Phillips, 1990. Por opção metodológica - com o objetivo de não contaminar os discursos produzidos por Albuquerque pela narração que dele fizeram os seus contemporâneos -, não utilizo neste ensaio as crônicas quinhentistas que descrevem, profusamente, os feitos de Albuquerque, caso das Lendas da India de Gaspar Correia, a História das conquistas dos portugueses na India de Fernão Lopes de Castanheda e as Décadas da Ásia de João de Barros, para não falar dos Comentários de Brás de Albuquerque.

${ }^{10}$ Claudio Guillen, "Notes towards the study of Renaissance Letter", In: Barbara Kiefer Lewalski (org.), Renaissance genres: essays on theory, history and interpretation, Harvard, Harvard University Press, 1986; Antonio Castillo, "Introducción", In: Editorial, 1999, p. 19-38.
} 
muito curtas, nas quais Albuquerque dá conta, e apenas, de pequenas questões. Como assinalou Francisco Bethencourt num inspirador estudo comparativo sobre a correspondência de Albuquerque e Cortès, data de 1513 e 1514 o volume maior dessa correspondência (dois terços do total), a qual é redigida, sobretudo, entre outubro e novembro, de modo a poder seguir na frota que partia para Lisboa nessa altura. ${ }^{11} \mathrm{Ou}$ seja, essas cartas são de um período balizado pelas principais conquistas de Albuquerque - Goa (1510), Malaca (1511) e Ormuz (1515) —, mas também quando já se tinham verificado alguns dos seus fracassos: Adém (1513). Datam também de um período em que as condições de conservação de tais conquistas começaram a ser definidas, destacando-se, dentre elas, o plano de controle de pontos-chave, a diplomacia e a conhecida "política de casamentos".

\section{A história politica de Quinhentos tem preferido a ação política em palcos europeus e mediterrânicos, raramente conectando estes com os palcos "ultramarinos"}

Num texto inteligente, Earle lembra ser impossível analisar as missivas de Albuquerque sem ter em conta o seu estatuto comunicativo. Desde logo, as cartas de Albuquerque respondiam às cartas que lhe tinham sido previamente enviadas por D. Manuel I, com instruções e também admoestações. Ao mesmo tempo, dialogavam com as missivas produzidas pelos seus rivais, muitas das quais instauravam um ambiente de controvérsia em relação à sua ação, o que potenciava, evidentemente, um discurso justificativo por parte de Albuquerque. ${ }^{12}$ Para além disso, a maior parte das cartas de Albuquerque faz parte de um universo maior de escrita que também as completa e autoriza: cadernos com informação detalhada sobre questões específicas - contabilidade, homens ao serviço, questões relativas ao estado das naus, entre outras - , mandados, conhecimentos, ordens etc. ${ }^{13}$

A par desses outros textos, parte deles desaparecidos, que instauram uma comunidade de discurso da qual as cartas de Albuquerque fazem parte, elas também são moldadas por seus interlocutores, suas expectativas e a imaginação que Albuquerque deles tinha (e vice-versa). Além de o diálogo com o rei

\footnotetext{
"Francisco Bethencourt, "The political correspondence of Albuquerque and Cortes", In: ___ ; Florika Egmond (orgs.), Correspondence and cultural exchange in Europe, 1400-1700, Cambridge, Cambridge University Press, 2007.

${ }^{12}$ John Villiers; Thomas Foster Earle (orgs.), Albuquerque, Caesar of the East: selected texts, Warminster, Aris \& Phillips, 1990, p. 49-51. O segundo capítulo do livro de Catarina Madeira Santos, Goa é a chave de toda a India: perfil político e institucional da capital do Estado da Índia, Lisboa, CNCDP, 1999, dá bem conta dessas trocas e tensões.

${ }^{13}$ Infelizmente, ainda está por fazer uma história material da documentação produzida por Afonso de Albuquerque, a sua preservação e transmissão, as suas características, as omissões, nomeadamente em comparação com a documentação produzida por outros governadores do império, seus contemporâneos e subsequentes.
} 
de Portugal ter uma dimensão explícita de resposta às solicitações e demandas feitas por aquele, o conteúdo dessas cartas também resulta da percepção que Albuquerque tinha do rei, não apenas enquanto vassalo, governador e cavaleiro da Ordem de Santiago - e todas as obrigações que esses estatutos implicavam -, mas também enquanto súdito que combinava todas essas identidades e não se reduzia a nenhuma delas. Não sabemos o que Albuquerque efetivamente pensava de D. Manuel, mas suas cartas declinam parte dessa imaginação que, não raras vezes, é bastante crítica. ${ }^{14}$ Daí a diferença entre as cartas para o rei e as cartas para Duarte Galvão, amigo de infância, humanista e cronista do reino, cuja conversação traduz um diálogo contínuo, iniciado em Lisboa desde os tempos de juventude e que continuava a ocorrer apesar da distância física. Ou a diferença com relação a outras cartas para outros interlocutores. ${ }^{15}$

Tendo presentes essas dimensões da correspondência disponível de Albuquerque, dela procurarei extrair, em primeiro lugar, dados relativos às suas ideias de conquista ${ }^{16}$ e de conservação de territórios. Em segundo lugar, privilegiarei todas as referências que aí se fazem à formação intelectual e à experiência política anteriores de Albuquerque. Se o primeiro exercício tem como objetivo averiguar a existência de um pensamento político consistente em Albuquerque, a reconstrução do quadro de conhecimentos e de experiências que ele transportou consigo quando partiu para o Índico permitirá perceber, por sua vez, o quadro de referências para o qual esse pensamento reenvia. Ao mesmo tempo, permite identificar os paralelos que existiam entre os mundos do florentino e do português.

As seções que se seguem exploram a sequência problemática exposta. A primeira parte é dedicada à identificação da tópica desenvolvida por Albuquerque relativamente à conquista e à conservação de territórios (com especial destaque para o papel aí desempenhado pela guerra). Sempre que considerar pertinente, essa identificação será feita em diálogo com a tratadística de Maquiavel. Na verdade, proponho uma operação muito simples, talvez demasiado simples: ler as cartas de Albuquerque tendo presente o que Maquiavel desenvolve sobre os mesmos temas em Il principe (uma síntese centrada no papel do governante no processo de conservação territorial), nos Discorsi (onde se encontra, nos livros $1^{\circ}$ e $3^{\circ}$, muita reflexão sobre a conservação de territórios e, no $2^{\circ}$ livro, matéria sobre a conquista) e no Dell'arte della guerra (exclusivamente dedicado à guerra, mas, curiosamente, menos estudado).

\footnotetext{
${ }^{14}$ Francisco Bethencourt, "The political correspondence of Albuquerque and Cortes", In: ___ ; Florika Egmond (orgs.), Correspondence and cultural exchange in Europe, 1400-1700, Cambridge, Cambridge University Press, 2007, p. 229

${ }^{15}$ Para Andrée Crabbé Rocha, A epistolografia em Portugal, Coimbra, Livraria Almedina, 1965, p. 65-67, Albuquerque "maneja a pena com o intemerato vigor de quem desembainha a espada", nada Ihe faltando "para ser um verdadeiro escritor".

${ }^{16}$ Sobre estas, veja-se o supracitado estudo de Fernando Gomes Pedrosa, Afonso de Albuquerque e a arte da guerra, Cascais, Câmara Municipal de Cascais, 1998, mas também os livros de João Paulo Oliveira Costa e Vitor Rodrigues: Conquista de Goa, 1510: campanhas de Afonso de Albuquerque, Lisboa, Tribuna, 2008 e Conquista de Malaca, 1511: campanhas de Afonso de Albuquerque, Lisboa, Tribuna, 2011, ou ainda a tese de José Virgílio Amaro Pissarra, A armada da India. Cômputo, tipologia e funcionalidade da armada de guerra portuguesa do Oriente (1501-1510), Dissertação de Mestrado, Universidade de Lisboa, Lisboa, 2001.
} 
Sabemos que Albuquerque não teve acesso à produção de Maquiavel — aliás, já tinha falecido quando Maquiavel redigiu os Discorsi e o Dell'arte della guerra-, e que Maquiavel não utilizou os "sucessos portugueses" como exemplos pertinentes para a sua reflexão, apesar de estar a par de muitos deles.

É provável que a imaginação eurocentrada e mediterrânica de Maquiavel não tenha antecipado - ao contrário do que aconteceu com outros humanistas florentinos - a relevância que as conquistas ultramarinas encetadas pelos ibéricos iriam ter no futuro europeu. Também se sabe que as tópicas dos tratados de Maquiavel nem sempre formam um todo coerente, denotando não apenas as mudanças do próprio autor diante das alterações políticas no mundo do qual fazia parte, mas também as rotinas de construção da escrita de uma época cuja retórica funcionava segundo parâmetros distintos dos atuais - potenciando, precisamente, as inconsistências textuais.

Comparativamente, a experiência de Albuquerque é simultaneamente mais vasta e mais reduzida. Mais vasta porque a sua ação desenvolveu-se em palcos europeus (Castela e Mediterrâneo ocidental), africanos (norte da África) e asiáticos (do Índico ocidental ao Índico oriental), traduzindo em suas cartas as conversações que estabeleceu com esses vários contextos e seus atores políticos e o conhecimento prático que tinha desses lugares e suas gentes; muito mais detalhado do que aquele que Maquiavel detinha, formatado (com exceção do império otomano) pelas leituras que fizera sobre aqueles territórios e gentes, considerados em permanente desvantagem quando comparados com os gregos e os romanos. ${ }^{17}$ Tomando as suas vidas como um todo, Albuquerque parece ter sido - e sei que essa é uma hipótese atrevida, mas que considero valer a pena ser enunciada - mais cosmopolita do que Maquiavel. $\mathrm{Ou}$, dito em outras palavras, Albuquerque teve mais experiência concreta dos mundos novos do que Maquiavel.

A par dessas diferenças estruturais, importa sublinhar outra igualmente relevante: enquanto as reflexões militares de Maquiavel incidem, sobretudo, sobre a guerra terrestre, as de Albuquerque privilegiam a guerra naval (sobre a qual não existe praticamente nada em nenhum dos livros de Maquiavel).

Dados os possíveis paralelos e as evidentes diferenças, se justifica, então, a pesquisa e a análise de conexões entre esses dois universos geograficamente tão distantes, politicamente tão distintos? Creio que sim, sobretudo se considerarmos a hipótese de os mundos nos quais Maquiavel e Albuquerque cresceram não serem, afinal, tão distintos, aspecto que será explorado na segunda parte deste estudo.

Mas, para recuperar esse tecido cultural comum, torna-se necessário adotar uma perspectiva transnacional das dinâmicas políticas e intelectuais da época moderna, adotando até o que Ulrich Beck e Nathan Snaizder designaram

${ }^{17} \mathrm{Na}$ verdade, quer I/ principe, quer os / discorsi como L’arte della guerra (ver edições online: Biblioteca della Letteratura Italiana. Disponível em: <http://www.letteraturaitaliana.net/>. Acesso em: 25 de maio de 2014, a partir de Mario Martelli, Machiavelli. Tutte le opere, Firenze, Sansoni, 1971) poucas referências têm à Ásia. O protagonista da obra L'arte afirma abertamente, aliás, que o seu raciocínio sobre a guerra incide sobre a Europa (Machiavelli, L'arte della guerra, p. 43). 
de "cosmopolitismo metodológico". ${ }^{18}$ Ou seja, fazer uma história que explora o cruzamento de uma série de variáveis menos visíveis, que inclui múltiplas vozes, uma história que permite entender, de forma mais rigorosa, a migração de linguagens políticas entre geografias distintas e identificar, dessa forma, as continuidades que se podem estabelecer entre dinâmicas históricas aparentemente descontínuas. Uma metodologia desse tipo implica identificar a recepção das culturas políticas asiáticas, africanas e ameríndias nos discursos políticos desenvolvidos pelos agentes portugueses (e europeus, em geral) que com eles entraram em contato, abandonando de vez as perspectivas difusionistas que continuam a procurar - e quase apenas - as influências que os modelos europeus exerceram noutros lugares. ${ }^{19}$ Implica mapear também os variados discursos sobre a conquista e conservação de territórios produzidos nessas décadas por outros europeus, de modo a identificar outras vias de comunicação cultural. ${ }^{20}$

Infelizmente, neste pequeno ensaio, não será possível perseguir esses dois desideratos. De momento, procurarei, e apenas, reconstruir a cultura intelectual de Afonso de Albuquerque e a materialidade dos contextos intelectuais daqueles com quem ele interagiu, de modo a identificar os veios transnacionais da sua cultura política e as possíveis pontes que podem ser estabelecidas entre as suas ideias de conquista e conservação territorial e as de Maquiavel. ${ }^{21}$

\section{"Pera averdes as riquezas quantas há no mundo": conquistar e conservar territórios no Índico ${ }^{22}$}

Numa carta ao rei D. Manuel datada de 16 de outubro de 1510, Albuquerque (governador do Estado da Índia entre 1509 e 1515) aconselha o rei a fazer guerra, contrariando algumas vozes contrárias, insistindo que "de bôoa guerra vem bôoa paz". No Índico, essa guerra tinha dois objetivos - expulsar o Islão e tornar o rei português num dos mais ricos do mundo. ${ }^{23} \mathrm{O}$ controle do comércio do Mar Vermelho suscitava enormes expectativas e o enriquecimento de D. Manuel (com frequência, Albuquerque repete esse topos de que poderia ter

\footnotetext{
${ }^{18}$ Ulrich Beck; Nathan Snaizder, "Unpacking cosmopolitanism for the social sciences: a research agenda”, The British Journal of Sociology, 2010, p. 381-403.

19 Uma conclusão semelhante pode ser retirada do texto de Annabel Bret, "Scholastic political thought and the modern concept of State", In: ___ James Tully (orgs.), Rethinking the foundations of modern political thought, Cambridge, Cambridge University Press, 2007. No caso das cartas de Afonso de Albuquerque, é muito clara a tensão entre poderio marítimo e terrestre, sendo que os príncipes locais duvidavam do poder dos portugueses porque estes, precisamente, não assentavam na terra.

${ }^{20}$ Dialogando, nomeadamente, com a proposta de Serge Gruzinski em L'aigle et le dragon. Démesure européenne et mondialisation au XVle siècle, Paris, Fayard, 2012.

${ }^{21}$ Ver as considerações a esse respeito de Sanjay Subrahmanyam, "The birth-pangs of Portuguese Asia: revisiting the fateful 'long decade' 1498-1509", Journal of Global History, n. 2, 2007, p. 261-280. Especificamente sobre o pensamento político de Afonso de Albuquerque, o único estudo disponível é o de Carlos Coimbra, $O$ pensamento político de Afonso de Albuquerque, Lisboa, Imprensa Nacional, 1932.

${ }^{22}$ Afonso de Albuquerque, "Carta a D. Manuel de 22-12-1512", In: __ Cartas de Afonso de Albuquerque seguidas de documentos que as elucidam, ed. Raymundo António Bulhão Pato, vol. 1, Lisboa, Academia Real das Sciencias de Lisboa, 1884, p. 35.

23/dem, "Carta a D. Manuel de 16-10-1510"; “Carta a D. Manuel de 4-12-1513”, In: Ibidem, p. 20; 226.
} 
dinheiro suficiente para "todalas as despesas do mumdo quamtas quiserdes fazer") constituía a consequência natural da diminuição do poder islâmico, atacado no coração caso se conseguisse controlar o seu centro de gravidade.

Mas o que permitia alcançar objetivos tão ambiciosos? Segundo Albuquerque, era necessário reunir um conjunto de condições. Desde logo, construir a reputação da força. Para que o rei fosse respeitado nos mares do Índico, tornava-se necessário que os outros príncipes temessem as suas capacidades. "Sabe vossa alteza que manha he a dos mouros de quá?", pergunta Albuquerque retoricamente ao rei. Logo a seguir, oferece a resposta: "a principal cousa em que se logo trabalham, em saberem quaamta jemte somos, que armas trazemos; e se nos vêm força com que eles nam possam, emtam nos rrecebem bem e nos dam as suas mercadorias". Mostrar essa força foi uma das estratégias privilegiadas por Albuquerque e uma das formas de alcançar essa fama havia sido, sempre que necessário, recorrer à punição exemplar dos inimigos. De acordo com isso, pede ao rei que tome "sempre vimgança dos Rex e senhores da imdia que uos errarem", porque isso era das "cousas que mais compre nestas partes pera vossa fama e credito". 24

A conquista de Goa exemplifica esse tipo de convicção. Albuquerque fez uma exibição do poderio naval dos portugueses com a intenção de sugerir que podia "vir sobre goa com mais naos, se quysera, e poor fazer esta mostra á yndia", de modo a que os inimigos fossem "certeficados do poder e gramdeza de vosas armadas e como podemos ajumtar vimte, trimta e qorenta naos, se comprir". Essa mostra de força "soará em toda parte, e com este temor e espamto fará vir gramdes cousas á vossa obediencia, sem nas comquystardes, e as senhoreardes".25

Albuquerque estava convencido de que, além de facilitar a conquista, a fama da força facilitaria doações voluntárias de territórios, bem como rendições de príncipes receosos de serem atacados pelo poderio português. Um raciocínio análogo encontra-se em Maquiavel. Ao discorrer sobre a relação entre virtus e fortuna na construção da grandeza de Roma e contestando as teses de Plutarco e de Tito Lívio, segundo os quais seria graças à fortuna que os romanos tinham alcançado tamanho império, para Maquiavel tinha sido a virtus (e esta expressava-se, nomeadamente, na força) que permitira aos romanos criar temor nos povos vizinhos, evitando que estes os atacassem. ${ }^{26}$

Todavia, a fama da força não dependia apenas das armas. Também era essencial boa gente e que os exércitos de que se dispunha fossem qualificados. "Boas fortalezas, muita jemte de cavallo, muita artelharia e bõos armas" - esse

\footnotetext{
${ }^{24}$ Afonso de Albuquerque, "Carta a D. Manuel de 16-10-1512"; "Carta a D. Manuel de 22-12-1512”, In: __ Cartas de Afonso de Albuquerque seguidas de documentos que as elucidam, ed. Raymundo António Bulhão Pato, vol. 1, Lisboa, Academia Real das Sciencias de Lisboa, 1884, p. 19-21; 40. 25/dem, "Carta a D. Manuel de 17-10-1510"; "Carta a D. Manuel de 22-12-1510", In: __. Ibidem, p. 21-23; 26-29; 49. ${ }^{26}$ Machiavelli, / discorsi sopra le Decade, Livro 2, cap. 1 (ver edição online: Biblioteca della Letteratura Italiana. Disponivel em: <http://www.letteraturaitaliana.net/>, a partir de Mario Martelli, Machiavelli. Tutte le opere, Firenze, Sansoni, 1971. Acesso em: 17 de junho de 2014).
} 
enunciado sintetiza as condições que Albuquerque considera necessárias para a Índia, reconhecendo, porém, não ser aquilo de que dispõe, mas apenas de "meia dúzia de navios podres e de mil e quinhentos homens". ${ }^{27}$ A necessidade de gente e armas é uma tópica recorrente na correspondência e a insatisfação diante de sua escassez é igualmente constante. Apesar disso, reconhece-se o envio de gente e o impacto que este sempre tinha. Segundo Albuquerque, após a chegada de novos contingentes, "de todollos lugares me escreveram loguo todollos Rex e Senhores muytos oferecimentos, mais com medo que per suas vomtades, e tudo isto está asosegado". ${ }^{28} \mathrm{O}$ envio de "capitães da suiça" que requerera em 1512, para "imsinar esta jemte que de lá vem, de quinhemtos ps., a nam fogir nem pôr em desbarato, a outra que tem mais obrigaçam a darem bõoa comta de sy", é considerado, dois anos mais tarde, "a mayor mercee do mundo". ${ }^{29} \mathrm{Na}$ verdade, o que Albuquerque desejava era estabelecer ordenanças, isto é, exércitos organizados, estáveis, regulares, que combinavam infantaria e artilharia, com os quais poderia sempre contar. ${ }^{30}$

Para que o rei fosse respeitado nos mares do Índico,
tornava-se necessário que os outros príncipes temessem
as suas capacidades. "Sabe vossa alteza que manha he
a dos mouros de quá?", pergunta Albuquerque

Força e reputação, desde que assentes sobre um poderio naval e tropas organizadas, eram, por conseguinte, as condições essenciais para se realizar uma boa conquista. A essas condições, Albuquerque aduz, ainda, algumas outras. Por um lado, o conhecimento. Desde logo, conhecer antecipadamente as condições locais era fundamental para ter sucesso nos avanços militares. São frequentes enunciados como: "tenho isto sabido per certa ciemcia pollos mesmos mouros", "avida toda a emformaçam de todalas cousas de demtro do mar Roxo, alguas vistas per mim", e sabemos, na realidade, que foram muitos os relatórios pedidos por Albuquerque. A Summa oriental de Tomé Pires e o Livro do que vio Duarte Barbosa são os exemplos mais conhecidos de entre os

\footnotetext{
${ }^{27}$ Afonso de Albuquerque, "Carta a D. Manuel de 22-12-1512", In: __. Cartas de Afonso de Albuquerque seguidas de documentos que as elucidam, ed. Raymundo António Bulhão Pato, vol. 1, Lisboa, Academia Real das Sciencias de Lisboa, 1884, p. 35.

28/dem, "Carta a D. Manuel de 18-10-1512"; “Carta a D. Manuel de 16-10-1510”; "Carta a D. Manuel de 1-4-1512”; "Carta a D. Manuel de 9-10-1512"; "Carta a D. Manuel de 30-10-1512"; "Carta a D. Manuel de 30-11-1513”, In: Ibidem, p. 1920; 29-65; 83; 91; 95 et seq.; 135 et seq.

29/dem, "Carta a D. Manuel de 16-10-1512", In: Ibidem, p. 19-21.

30Ver, a esse propósito, Fernando Gomes Pedrosa, Afonso de Albuquerque e a arte da guerra, Cascais, Câmara Municipal de Cascais, 1998, p. 61; 89 et seq.
} 
variados que podiam ser compulsados. ${ }^{31}$ Em seguida, conhecer as condições sociais e políticas dos lugares a conquistar, o que permitia, por exemplo, explorar as divisões dos poderes locais sempre que estas existiam. O fato de que "os turqos são deuisos amtre sy" facilitava essa empresa e, por essa via, a conquista de alguns dos territórios que estes dominavam. No geral, Albuquerque considerava que os "gentios" eram "homens cheos de novidades", característica que facilitava a sua captação para o partido português em troca de dinheiro e de privilégios no mar: "se acharem capitam português que dê escalla franqa e soldo, são logo cem mil piães com elles, e tomam a Remda da terra em pagamento de seos soldos". ${ }^{32}$ Em suma, comprar amizades e contratar soldados locais era relativamente fácil, o que também favorecia o sucesso da conquista.

Por outro lado, a providência divina, já que, sem o seu apoio, qualquer empresa podia estar condenada ao fracasso. Albuquerque repete frequentemente a ideia de que os sucessos da Índia "parecem cousas ordenadas por Deos". ${ }^{33}$ Numa missiva, dizia estar convencido de que, com a "ajuda da paixam de nosso senhor", conseguirá alcançar a "destroyção de meca". ${ }^{34}$ Matéria cuja centralidade na política manuelina mereceu que Luís Filipe Thomaz lhe dedicasse um dos seus estudos mais emblemáticos, ${ }^{35}$ a "destroyçam de Meca, fim e acabamento da seyta de Mafamede, divisam e discordias amtre as suas seitas" era tópico onipresente entre as elites portuguesas desse período. Seria nesse contexto, aliás, que Albuquerque veria no céu "há grande cruz e muito crara e muito bem feita e muito Resprandecente", "mostrando nos nosso senhor aquelle sinal pera aquella parte do preste João omde se avia por mais servido de nós". ${ }^{36}$

Esse tipo de "sinal" levava Albuquerque a concordar plenamente com uma afirmação de Duarte Galvão, segundo o qual as coisas da Índia eram "divinalmente achadas e divinalmente sostidas [conservadas]". Para Albuquerque, até os seus sucessos em Malaca provavam que "nosso senhor traz o negocio da India na mao". Consciente de que o feito de Malaca tinha sido temerário, Albuquerque remete para a sua lealdade divina a decisão de o fazer: "Fiz meu caminho via de Malaca, porque a nosso senhor aprazia", admitindo ainda que "deixei eu a India nom como me elRey mandava, mas como homem que avia de dar Rezão della neste mundo e no outro". Toda a carta está cheia de alusões

\footnotetext{
${ }^{31}$ Afonso de Albuquerque, "Carta a D. Manuel de 4 de dezembro de 1513", In: Cartas de Afonso de Albuquerque seguidas de documentos que as elucidam, ed. Raymundo António Bulhão Pato, vol. 1, Lisboa, Academia Real das Sciencias de Lisboa, 1884, p. 226 et seq.

32/dem, "Carta a D. Manuel de 22-12-1510", In: Ibidem, p. 26-29.

33/dem, "Carta a D. Manuel de 3-12-1513", In: Ibidem, p. 196.

${ }^{34}$ /dem, “Carta a Duarte Galvão", In: Ibidem, p. 395 et seq.

${ }^{35} \mathrm{O}$ imaginário político da Corte portuguesa estava imbuído de um providencialismo que podia ter, inclusive, laivos proféticos e milenaristas, como foi já salientado por Luís Filipe Thomaz, no seu seminal artigo "L'idée impériale manuéline", laivos esses que também caracterizavam, segundo Sanjay Subrahmanyam, o espaço euro-asiático (Luís Filipe Thomaz, "L'idée impériale manueline", In: Jean Aubin (org.), La Découverte, le Portugal et l'Europe - Actes du Colloque, Paris, Fondation Calouste Gulbenkian, 1990, p. 35-103)

${ }^{36}$ Afonso de Albuquerque, "Carta a Duarte Galvão", In: op cit., p. 395 et seq.
} 
desse tipo, quer para justificar o sucesso nas conquistas, quer para explicar uma fortuna especial num momento de perigo, quer ainda para justificar situações que lhe pareciam improváveis: "parece cousa de deus desejarem os portugueses tamto de casar e viver em Goa". ${ }^{37}$

Ou seja, Albuquerque situava as conquistas no Índico num plano simultaneamente temporal e escatológico, sendo que a fidelidade política ao rei parecia ser menor do que a sua fidelidade a Cristo. ${ }^{38}$

Como essa tensão seria interpretada por Maquiavel, caso ele tivesse considerado a ação de Albuquerque digna de reflexão? Partindo das leituras de Maquiavel propostas por Maurizio Viroli, diferentes da maior parte da doutrina sobre a relação que Maquiavel tinha com a religião (entendida, na maior parte das vezes, como estritamente funcionalista, liberta da dimensão escatológica), Maquiavel surge como um adepto de uma religião cristã reformada, uma religião que estimulava a virtus política e, por conseguinte, o bom cidadão. Viroli admite que, nos Discorsi, Maquiavel atribui a frouxidão da vida política italiana ao seu apego à religião católica, mas, segundo este autor, Maquiavel referia-se à religião católica tal como ela era vivida na Itália no seu tempo, e não à religião católica em geral. Ao contrário, para Maquiavel, uma religião genuína era motivadora da ação, era dinâmica; em suma, era virtuosa. ${ }^{39}$

Ora, a ação militar de Albuquerque era, em boa medida, motivada por uma religião desse tipo (como se verá, adiante, a família de Albuquerque esteve associada, desde cedo, a movimentos de reformismo religioso), muito embora nem sempre seja claro a que tipo de glória Albuquerque verdadeiramente aspirava. Pode-se questionar se ele procurava o reconhecimento temporal e, com ele, a reputação do seu príncipe e da sua "cidade", o que Maquiavel certamente aprovaria, ou o mero reconhecimento divino, isto é, a sua glória pessoal, tornando-o uma espécie de "mercenário de Deus" (o que o florentino criticaria). ${ }^{40}$

Em alternativa, Maquiavel poderia entender a relação que Albuquerque tinha com a providência divina como uma crença na fortuna, e não na virtus (apesar de, para Albuquerque, o favor divino resultar da sua virtus). Caso optasse por essa interpretação, Maquiavel criticaria Albuquerque por este acreditar que a "arbitrariedade" constituía uma variável importante na determinação dos sucessos e insucessos das conquistas. Para Maquiavel, que hoje poderíamos qualificar como um control freak [neurótico], a anulação da incerteza da circunstância era crucial para o sucesso dos negócios políticos.

\footnotetext{
${ }^{37}$ Afonso de Albuquerque, "Carta ao rei D. Manuel I de 22-13-1512", In: ___. Cartas de Afonso de Albuquerque seguidas de documentos que as elucidam, ed. Raymundo António Bulhão Pato, vol. 1, Lisboa, Academia Real das Sciencias de Lisboa, 1884, p. 56.

38/dem, "Carta ao rei D. Manuel I de 30-11-1513", In: Ibidem, p. 135.

${ }^{39}$ Maurizio Viroli, Machiavelli's god, Princeton, Princeton University Press, 2010, Prefácio

${ }^{40}$ Essa interpretação seria possível a partir das teses desenvolvidas por Timothy J. Lukes, "Martialing

Machiavelli: reassessing the military reflections", Journal of Politics, vol. 66, n. 4, 2004, p. 1089-1108.
} 
Deixando em aberto tais incertezas interpretativas, quais são os pontos em que Maquiavel e Albuquerque divergem explicitamente? Desde logo, o papel que a desunião política e social nas cidades ou territórios a conquistar podia desempenhar. Das cartas de Albuquerque, depreende-se que a desunião política e social dos territórios a conquistar constituía um fator adjuvante da conquista. Os portugueses tornaram-se peritos em explorar essas divisões, aliando-se, habitualmente, a facções descontentes, de modo a alcançar os resultados pretendidos. É sem dúvida diferente o que Maquiavel sugere nos Discorsi. Maquiavel não aconselhava o recurso a esse mecanismo, já que estava convicto de que, em muitas situações, um ataque externo podia servir de elemento catalisador da coesão interna, gerando um efeito de força inesperado que comprometeria, por essa via, o sucesso do ataque. O intuito de Maquiavel é claro: mais do que explorar as divisões internas do inimigo - e depender de fatores exógenos -, era por meio de um exército potente e temível que uma entidade política podia expandir-se e aumentar os seus territórios; ou seja, dependendo, sobretudo, de fatores endógenos. É certo que em Il principe, Maquiavel é menos taxativo, aceitando que era quase impossível não ter o favor interno para conquistar uma nova província. ${ }^{41}$ Todavia, sete anos mais tarde, parece dar menos importância a essa variável, privilegiando, em vez disso, a consistência da comunidade política.

É o mesmo princípio - a tensão entre variáveis endógenas e exógenas - que leva Maquiavel a criticar o uso de mercenários. Ele próprio envolvido na criação de uma milícia florentina, em 1506, Maquiavel discorre amplamente sobre esse tema em Il principe, nos I discorsi e no Dell'arte della guerra. Para alguns autores, Maquiavel estava verdadeiramente convicto de que Florença não conseguia expandir-se territorialmente por depender de exércitos compostos por mercenários e auxiliares, razão pela qual encetara uma defesa explícita de exércitos constituídos por cidadãos, os únicos que permitiam que as aspirações e estabilidade dos principados não dependessem da fortuna, mas sim da virtus. ${ }^{42}$ Os exércitos compostos por mercenários dificilmente teriam um amor genuíno ao príncipe e à pátria pela qual combatiam que justificasse a luta por estes em qualquer circunstância. ${ }^{43}$ Recorrendo ao exemplo dos romanos, Maquiavel considerava que a expansão imperial dependia, em boa medida, da qualidade dos exércitos compostos por cidadãos, os quais se tinham mostrado igualmente essenciais para a estabilidade política (isto é, para a conservação da república). Tais exércitos seriam tanto mais virtuosos quanto combinassem as boas técnicas romanas com algumas

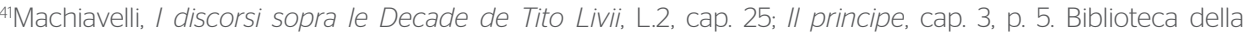
Letteratura Italiana. Edição feita a partir de Mario Martelli, Machiavelli. Tutte le opere, Firenze, Sansoni, 1971. Disponível em: <http://www.letteraturaitaliana.net/>. Acesso em: 17 de junho de 2014. ${ }^{42}$ Mikael Hörnquist, "Machiavelli's military project and the Art of war", In: John M. Najemy (org.), The Cambridge companion to Machiavelli, Cambridge, Cambridge University Press, 2010, p. 113-118.

${ }^{43}$ Machiavelli, op cit., cap. 20; caps. 12-14.
} 
das novidades dos seus tempos - nomeadamente as desenvolvidas pelos "tudescos" e pelos "suíços". ${ }^{4}$

Como é sabido, a empresa portuguesa no Índico era composta por uma mescla de soldados, entre os quais abundavam os mercenários, para além dos tais "cem mil piães" que um capitão português facilmente conseguia arregimentar, desde que tivesse condições para lhes pagar. Apesar de estar em consonância com a cultura militar dominante, era exatamente o oposto daquilo que Maquiavel defendia. Ao mesmo tempo, e como se viu anteriormente, Albuquerque estava consciente dos riscos referidos pelo florentino, razão pela qual pedira ao rei, precisamente, que enviasse guardas suíços. ${ }^{45}$

Também a sua política em relação às fortalezas vai ao contrário do que é defendido por Maquiavel, ainda que esteja próximo, por seu turno, do que era comum na época e do que viria a ser teorizado um século mais tarde por outros estrategas do poder. ${ }^{46}$ Para Maquiavel, as fortalezas serviam para defender o príncipe dos "conquistados", revelando, nesse caso, um "mau príncipe", ou para o defender dos inimigos externos, caso em que a sua utilidade dependia da existência ou não de um bom exército. ${ }^{47}$ Havendo um bom exército, as fortalezas tornavam-se quase desnecessárias, pois cabia ao exército, sobretudo, a ação de defesa. E caso o exército fosse mau, as fortalezas tornavam-se danosas. A esse respeito, Albuquerque segue, mais uma vez, o pensamento dominante na época, que aconselhava a fortificação dos territórios sob domínio. E mais: no caso do Índico, essa cintura de fortalezas seria uma parte integrante do plano de conservação territorial, considerando Albuquerque sempre insuficientes os esforços realizados pela Coroa no sentido de garantir a segurança das conquistas.

Para a "imdia tomar asemto", dizia Albuquerque, "por três anos teria neela três mil homens bem armados e bõos aparelhos de fazer fortalezas e muytas armas", para concluir, inclusive, que "as cousas destas partes assenhoreadas de vossalteza com bõoa fortaleza ["mas a portugueses cos capacetes amtras ameyas"], que huma vez tomarem asemto, teloam até fim do juízo" ${ }^{48}$ As fortalezas eram tão importantes para Albuquerque que, em dezembro de 1512,

\footnotetext{
${ }^{44}$ Machiavelli, L’arte della guerra, livro 2 (ver edições online: Biblioteca della Letteratura Italiana. Disponível em: <http://www.letteraturaitaliana.net/>. Acesso em: 25 de maio de 2014). Ver, a esse propósito, as considerações de Timothy J. Lukes, "Martialing Machiavelli: reassessing the military reflections", Journal of Politics, vol. 66, n. 4, 2004, p. 1089-1108.

${ }^{45}$ Afonso de Albuquerque, "Carta a D. Manuel de 16-10-1510", In: ___. Cartas de Afonso de Albuquerque seguidas de documentos que as elucidam, ed. Raymundo António Bulhão Pato, vol. 1, Lisboa, Academia Real das Sciencias de Lisboa, 1884, p. 19-20.

${ }^{46}$ Fernando Gomes Pedrosa, Afonso de Albuquerque e a arte da guerra, Cascais, Câmara Municipal de Cascais, 1998, p. 103-107. Sobre essa cultura de fortificação e sua prática em Portugal, veja-se Andréa Doré, Sitiados. Os cercos às fortalezas na India (1498-1622), São Paulo, Alameda, 2010, p. 75 et seq.

${ }^{47}$ Machiavelli, / discorsi sopra le Decade de Tito Livii, livro 2, cap. 24. Biblioteca della Letteratura Italiana. Edição feita a partir de Mario Martelli, Machiavelli. Tutte le opere, Firenze, Sansoni, 1971. Disponível em: <http://www. letteraturaitaliana.net/>. Acesso em: 17 de junho de 2014.

48"amtras ameyas": entre as ameias (dos castelos). Vítor Rodrigues, "A guerra na India", In: António Manuel Hespanha (org.), Nova história militar de Portugal, vol. 2, Manuel Themudo Barata; Nuno Severiano Teixeira (dirs.), Lisboa, Círculo de Leitores, 2004, p. 200-201; Afonso de Albuquerque, "Carta a D. Manuel I de 1-4-1512"; "Carta a D. Manuel de 22-12-1512"; "Carta a D. Manuel de 30-10-1512", In: op cit., p. 33; 40; 51; 54; 97.
} 
adverte o rei da seguinte maneira: segundo ele, se não se fizessem fortalezas nos "lugares primcipaes", "nam avees de meter a India a caminho, ou temde sempre hum peso de jemtes nestas partes" ${ }^{49} \mathrm{Ou}$ seja, ao contrário de Maquiavel, para quem as fortalezas sem gente eram praticamente inúteis, para Albuquerque, elas constituíam-se como a única alternativa à escassez de recursos humanos..$^{50}$

Lugares há, porém, em que o florentino e o português parecem estar em sintonia: reputação, amizades políticas, algumas técnicas de conquista. Une-os, desde logo, a convicção de que a fama do príncipe era um fator crucial para o sucesso na guerra. A percepção do poderio do príncipe dissuadia os inimigos de o atacarem, podendo ser este, ao contrário, a decidir quando e como fazê-lo. ${ }^{51}$ Por seu turno, Maquiavel também considera - tal como Albuquerque - que ter um amigo na cidade ou província a conquistar era relevante, pois facilitava a entrada na mesma, ${ }^{52}$ ainda que, e ao contrário de Albuquerque, associe essa amizade ao efeito positivo provocado pela reputação do príncipe - o qual atraía para junto de si muitos amigos - e não tanto às desuniões políticas no interior do território a adquirir. ${ }^{53}$

$$
\begin{aligned}
& \text { Lugares há, porém, em que o florentino e o } \\
& \text { português parecem estar em sintonia: reputação, } \\
& \text { amizades politicas, técnicas de conquista }
\end{aligned}
$$

As cartas de Albuquerque mostram-nos, ainda, que havia semelhanças relativamente às táticas a adotar na conquista. Para Maquiavel, as melhores guerras eram as curtas e os melhores ataques eram os ataques em força, com violência aberta, muito embora procurando destruir o menos possível. ${ }^{54}$ Também Albuquerque procura concretizar a mesma ideia, mas ao nível da guerra naval: ataques curtos e com força, numa combinação entre

\footnotetext{
${ }^{49}$ Afonso de Albuquerque, "Carta a D. Manuel de 22-12-1512", In: __. Cartas de Afonso de Albuquerque seguidas de documentos que as elucidam, ed. Raymundo António Bulhão Pato, vol. 1, Lisboa, Academia Real das Sciencias de Lisboa, 1884, p. 39.

${ }^{50}$ Aliás, essa seria a interpretação de Carlo Theti no Discorsi delle fortificationi, espugnatione \& diffese delle città, \& d'altri luoghi, de 1589, apud Andréa Doré, Sitiados. Os cercos às fortalezas na India (1498-1622), São Paulo, Alameda, 2010, p. 77.

${ }^{51}$ Machiavelli, I discorsi sopra le Decade de Tito Livii, L. 2, cap. 1. Biblioteca della Letteratura Italiana. Edição feita a partir de Mario Martelli, Machiavelli. Tutte le opere, Firenze, Sansoni, 1971. Disponível em: <http://www. letteraturaitaliana.net/>. Acesso em: 17 de junho de 2014.

52/bidem.

53/bidem, cap. 1; cap. 30.

${ }^{54}$ Ainda no livro 2 dos / discorsi, nos capítulos 6 e 32. Ibidem.
} 
poderio naval e capacidade da artilharia que substituía, com vantagem, os métodos tradicionais. ${ }^{55}$

Poder-se-ia continuar esse mapeamento dos pontos de divergência e de contato entre Maquiavel e Albuquerque no que diz respeito à conquista de novos territórios. Para além do que já foi sendo referido - já que, tanto para Maquiavel quanto para Albuquerque, conquista e conservação estavam profundamente interligadas -, o que sucede quando se analisam as suas reflexões sobre as condições que permitiam a conservação desses territórios? Essas reflexões podem ser divididas em dois tipos: as de natureza mais geopolítica e as que dizem respeito ao governo das populações.

O estabelecimento de uma rede de cidades que se entreajudavam, na qual Goa desempenhava um papel central, era uma das condições mais importantes para a sustentabilidade das conquistas. Goa, segundo Albuquerque, não requeria muita gente para a sua defesa (cerca de 400 homens), apesar de poder sustentar "dous e tres e quatro mill homens". A par disso, Goa era autossustentável do ponto de vista demográfico e econômico. ${ }^{56}$ Acrescia a essas mais-valias o fato de, em caso de se verificar a perda da "Ymdia", "de goa a podês tornar a ganhar e comquistaar". Além disso, era a partir de Goa que "poderiam as vosas gemtes emtrar o Reino de daquém e de narsynga”, isto é, avançar na conquista propriamente territorial. ${ }^{57}$

As restantes cidades dessa liga eram Cochim, "escapola principall e feitoria principall de todo o da Imdia, por estar no meo de todallas cousas e he navegaçam de todas as feitorias, que vos conveem ter na Imdia pera averdes proveito; Adém, por se situar na 'boca e navegaçam do estreyto', aí passando todas as naus que vinham de Judá para a Índia; Ormuz, que tinha 'mester peso de jemte, e boom comselho que a gouerne e tenha a dereito, porque ela pagará tudo, e asy como obriga a muito, asy Remde muito, e he ha muy primcipall antre todalas da imdia e muy gramde' e Malaca, 'muito grande cousa". 58

Um dos estudos mais importantes sobre o Estado da Índia incide, precisamente, sobre o caráter fundacional desse modelo e o seu alcance na estruturação da experiência imperial portuguesa. Segundo Luís Filipe Thomaz, Albuquerque inspirou-se nas experiências imperiais gregas (minoicas e atenienses), na liga hanseática e, certamente, no império aragonês, para propor uma rede de cidades fortificadas como estrutura político-administrativa do Estado da Índia. A combinação entre um domínio essencialmente marítimo,

\footnotetext{
${ }^{55}$ Vitor Rodrigues, "A guerra na Índia”, In: António Manuel Hespanha (org.), Nova história militar de Portugal, vol. 2, Manuel Themudo Barata; Nuno Severiano Teixeira (dirs.), Lisboa, Círculo de Leitores, 2004, p. 198.

${ }^{56}$ Afonso de Albuquerque, "Carta a D. Manuel de 17-10-1510", In: ___ Cartas de Afonso de Albuquerque seguidas de documentos que as elucidam, ed. Raymundo António Bulhão Pato, vol. 1, Lisboa, Academia Real das Sciencias de Lisboa, 1884, p. 22.

57/dem, "Carta a D. Manuel de 22-12-1510", In: Ibidem, p. 26-29.

58/dem, "Carta a D. Manuel de 1-4-1512"; "Carta a D. Manuel de 4-12-1513"; "Carta a D.Manuel de 22-9-1515", In: Ibidem, p. 53; 199 et seq: 370.
} 
assente sobre um forte poderio naval e reforçado pelo controle de pontoschave, caracterizaria esse modelo. ${ }^{59}$ Não discordando da interpretação de Thomaz relativamente a esse período inicial do Estado da Índia, creio que considerar as reflexões as quais Maquiavel fez sobre as ligas com cidades (adicionando-as às que Thomaz considera) e as vantagens que estas tinham trazido para o engrandecimento de Roma pode ser igualmente útil. Para Maquiavel, o modelo de liga de cidades com maior sucesso tinha sido, precisamente, o estabelecido por Roma, o qual permitira o engrandecimento daquela e do seu projeto de expansão territorial. ${ }^{60}$ Goa, a Roma do Oriente, não viria a evocar, também, essa outra experiência? Na senda do que já foi intuído por Catarina Madeira Santos, diria que sim. ${ }^{61}$

Para a conservação territorial, a vontade do príncipe era igualmente crucial. Para o governador do Estado da Índia, era claro que o rei D. Manuel devia preocupar-se mais com a conservação das suas conquistas do que com aquelas que tinham sido alcançadas pelos seus antecessores (em África, nomeadamente), lamentando-se por o rei desfavorecer "as cousas de vossa vitoria e vossa fama tam lomje de vossos rregnos, tam gramdes e tam rricas". E mais: segundo Albuquerque, o rei deveria dispor de recursos financeiros para assegurar a permanência em várias frentes nas quais se encontrava envolvido - o palco da Índia e da África, a ajuda aos "amigos" com grandes armadas, as naus que mandava fazer, as armadas que mandava ao estreito - , pelo que importava tomar opções de modo a poder conservar o que de mais valioso possuía. ${ }^{62}$

Mas o príncipe também tinha um papel importante no desenhar do governo das populações que residiam nos territórios imperiais. À semelhança do que Maquiavel defendeu, em 1503, no parecer "Del modo di trattare el popolo della Valdicchiana ribellati" (apesar de posteriormente, e mais uma vez, ter assumido posicionamentos ligeiramente distintos), em Goa parece ter sido aplicado um raciocínio semelhante: ou a destruição total e violenta, ou o tratamento benévolo dos vencidos. ${ }^{63}$

\footnotetext{
${ }^{59}$ Luís Filipe Thomaz, "A estrutura político-administrativa do império português, In:__, De Ceuta a Timor, Lisboa, Difel, 2004; Idem, "Albuquerque”, In: Joel Serrão (org.), Dicionário de história de Portugal, vol. 1 (A-C), Porto, Livraria Figueirinhas, 1979; António Manuel Hespanha; Catarina Madeira Santos, "Os poderes num império oceânico", In: António Manuel Hespanha (org.); José Mattoso (dir.), História de Portugal. O Antigo Regime (1620-1807), vol. 4, Lisboa, Círculo de Leitores, 1993; António Manuel Hespanha, "A constituição do império português. Alguns enviesamentos historiográficos”, In: João Fragoso; Maria Fernanda Bicalho; Maria de Fátima Gouveia (orgs.), O Antigo Regime nos trópicos: a dinâmica imperial portuguesa (séculos XVI-XVIII), Rio de Janeiro, Civilização Brasileira, 2001; Kirti Chaudhuri, "O estabelecimento no Oriente", In: Francisco Bethencourt; Kirti Chaudhuri (orgs.), História da expansão portuguesa, vol. 1, Lisboa, Círculo de Leitores, 2008, p. 163-191.

${ }^{60}$ Mikael Hörnquist, Machiavelli and empire, Cambridge, Cambridge University Press, 2004, p. 131 et seq; Machiavelli, Discorsi sopre le Decade de Tito Livii, livro 2, cap. 5. Biblioteca della Letteratura Italiana. Edição feita a partir de Mario Martelli, Machiavelli. Tutte le opere, Firenze, Sansoni, 1971. Disponível em: <http://www. letteraturaitaliana.net/>. Acesso em: 17 de junho de 2014.

${ }^{61}$ Catarina Madeira Santos, Goa é a chave de toda a India. Perfil político da capital do Estado da Índia, Lisboa, CNCDP, 1999, p. 113 et seq.

${ }^{62}$ Afonso de Albuquerque, "Carta a D. Manuel I, 1-4-1512", In: Cartas de Afonso de Albuquerque seguidas de documentos que as elucidam, ed. Raymundo António Bulhão Pato, vol. 1, Lisboa, Academia Real das Sciencias de Lisboa, 1884, p. 33 et seq.

${ }^{6}$ Técnicas explicitamente defendidas por Maquiavel em "Del modo di trattare el popolo della Valdicchiana ribellati" apud Mikael Hörnquist, op cit., p. 103.
} 
Atente-se na descrição que Albuquerque oferece na carta a D. Manuel de 22 de dezembro de 1510: por um lado, Albuquerque estava determinado em "nom deixar viver mouro em Goa, nem entrar nela"; por outro, mostrava benevolência em relação a alguns escolhidos: "deixar gente por agora aquela que bem me parecer"; "os lavradores da terra e bramenes mandei que nam matassem"; "dei seguro ao povo meudo e ofyciaes, calafates e carpimteiros, ferreiros, pintores, e logo teremos abastança d oofficiaes pera tudo o necesairo" ${ }^{64}$ Isto é, a solução gizada por Albuquerque combinava violência e benevolência.

Tratar bem os mouros também podia ser equacionado, como dá conta numa carta de 23 de novembro de 1512, na qual afirma que "os mouros desta terra sabem bem ho amor que eu lhes tenho e como lhes crio, e a comfiança que neles tenho". ${ }^{65}$ Ou seja, tal como em Maquiavel, também com Albuquerque era a análise da circunstância a ditar a melhor decisão, reenviando para um universo de escolhas que, curiosamente, tinha muitas semelhanças com o que era preconizado pelo florentino.

A par do relacionamento com as populações locais, a relação do príncipe com os "colonizadores" também era essencial. Particularmente atento à "psicologia do colono", Albuquerque refere-se com frequência à necessidade de controlar a incerteza, de modo a não estimular a desmotivação e laxismo dos portugueses estabelecidos no Índico. ${ }^{66} \mathrm{Um}$ dos modos de o fazer era promover casamentos entre soldados portugueses e mulheres indianas, multiplicando, por essa via, a comunidade portuguesa local e garantindo, por meio dela, a continuidade da presença imperial. ${ }^{67}$ Acresciam a esses, fatores menos controláveis, como o caso da dissimulação dos reis indianos e também da fortuna, nem sempre favorável aos portugueses. A propósito da falhada conquista de Adém, numa carta de 1513, explica que "todos eses capitãees, cavaleiros e fidalgos pegados no muro, e o emtraram tam ousadamemte e com tamto esforço e desejos de vos servir, como se vos alteza e pesoa estivera aly e os vira". Todavia, "a furtuna, emvejosa de suas homras, quys qe qebrasem as escadas jumtamemte todas", contrariando, inclusive, a "ajuda de noso senhor", com a qual teriam "ho feito acabado, qe na cidade nam avia jemte pera nas Ruas delas ousarem de pelejer comnosco". A referência a esse combate entre a "fortuna", a velha deusa romana, e a providência, ganho pela primeira, é muito interessante por aquilo que indicia sobre a imaginação intelectual de Albuquerque, oscilando entre o seu quadro cristão e uma cultura clássica partilhada pelas elites da época e expressa de forma tão sugestiva nesse pequeno enunciado.

\footnotetext{
${ }^{64}$ Afonso de Albuquerque, "Carta a D. Manuel de 22-12-1510", In: __. Cartas de Afonso de Albuquerque seguidas de documentos que as elucidam, ed. Raymundo António Bulhão Pato, vol. 1, Lisboa, Academia Real das Sciencias de Lisboa, 1884, p. 26-29.

65/dem, "Carta a D. Manuel de 23-11-1512", In: Ibidem, p. 100.

${ }^{66}$ Anthony John Russell-Wood, “Fronteiras de integração"; "A sociedade portuguesa no Ultramar”, In: Francisco Bethencourt; Kirti Chaudhuri (orgs.), História da expansão portuguesa, vol. 1, Lisboa, Círculo de Leitores, 2008, p. 238-281.

${ }^{67}$ Afonso de Albuquerque, "Carta ao rei D. Manuel de 1-4-1512", In: op cit., p. 33.
} 
Como esse tipo de discurso pode ser relacionado com o muito que Maquiavel escreveu sobre a conservação de novos territórios, tanto em Il principe quanto nos I discorsi? É impossível sintetizar, com a merecida complexidade, o pensamento de Maquiavel sobre esses temas no espaço deste estudo. Assim, limitar-me-ei a relembrar algumas ideias conhecidas que o florentino desenvolveu em torno dessas temáticas.

Para Maquiavel, era claro, em primeiro lugar, que o tipo de conquista (dependente da virtus ou da fortuna) era uma variável importante para a posterior conservação dos territórios conquistados. Uma conquista resultante da força dos exércitos tinha mais possibilidades de conservação do que uma conquista que resultara de uma combinação de fatores mais ou menos conjunturais. Em todo o caso, era sempre grande o conjunto de dificuldades que a conservação de territórios novos encerrava, a começar pela impossibilidade de o príncipe satisfazer os desejos de todos aqueles que o tinham ajudado ${ }^{68}$ Essas dificuldades eram ainda maiores quando se conquistara uma "provincia disforme di lingua, di costumi, di ordine" (caso dos territórios conquistados por Albuquerque no Índico).

\section{Mais do que nas fortalezas, era nos recursos humanos - e na sua determinação em conservar os territórios onde viviam - que residia a chave para a sua conservação}

A manutenção desse tipo de províncias só era possível por meio da residência do novo príncipe na mesma, ou enviando colônias de súditos seus, os quais residiriam em lugares próximos entre si, por ser essa a única forma de evitar a dependência desse território de muita gente de armas, o que se tornava demasiado custoso, requerendo todos os ganhos que se obtivera com a conquista. Ou seja, mais do que nas fortalezas, era nos recursos humanos - e na sua determinação em conservar os territórios onde viviam - que residia a chave para a sua conservação. Atente-se nessa segunda solução, pelas semelhanças que ela tem com a "política dos casamentos" de Albuquerque. Segundo Maquiavel - como para Albuquerque - deviam distribuir-se casas e terras aos colonos que antes pertenciam a habitantes daqueles territórios, o que, evidentemente, era pouco oneroso, apesar de ofender aqueles a quem tais bens eram retirados. Contudo, desde que estes permanecessem pobres e dispersos, não só não havia perigo, como tal escolha servia de exemplo aos demais. Proteger os menos poderosos e enfraquecer os que tinham mais poder, e não deixar que a reputação dos estrangeiros crescesse, eram três instrumentos igualmente importantes — segundo Maquiavel - para conservar esse tipo de território. ${ }^{69}$

\footnotetext{
${ }^{68}$ Machiavelli, /l principe, cap. 6, cap. 7, p. 19-20, 22 et seq. Biblioteca della Letteratura Italiana. Edição feita a partir de Mario Martelli, Machiavelli. Tutte le opere, Firenze, Sansoni, 1971. Disponível em: <http://www. letteraturaitaliana.net/>. Acesso em: 17 de junho de 2014.

69/bidem, cap. 3.
} 
Enfim, esse sucinto diagnóstico mostra-nos que se podem estabelecer pontos de sintonia entre Maquiavel e Albuquerque, nomeadamente em relação a temas como a conexão entre força e reputação política, as melhores técnicas de conquista e o papel dos colonos na conservação dos territórios. Por seu turno, são claras as divergências relativas a outras dimensões igualmente centrais, tais como o papel que mercenários e fortalezas podiam/deviam ter na conquista e na conservação dos territórios, bem como o lugar que se atribui à fortuna (aqui também traduzida como providência divina), para os sucessos e insucessos das mesmas. Se as divergências não são surpreendentes, assinaladas que foram, logo no início, as diferentes biografias e percursos dos dois protagonistas deste estudo, já as convergências merecem uma explicação mais detalhada. Torna-se necessário, por conseguinte, revisitar os contextos culturais nos quais Afonso de Albuquerque se moveu.

\section{Um "gramde leterado" com "muita prudemcia, descriçam e saber"}

Um "gramde leterado" com "muita prudemcia, descriçam e saber": é esse o autorretrato de Afonso de Albuquerque numa carta escrita ao rei D. Manuel em 1513, acrescentando, na mesma missiva, que já tinha "hidade pera saber ho bem e o mal".70 Noutras cartas, Albuquerque volta a sublinhar as suas qualidades: não ter "criaçam nem condiçam" que lhe permitam desobedecer ao rei. Por essa razão, o seu serviço era desenganado e a sua diligência em executar as ordens do rei ("cá nesta terra nom se faz cousa senom justamente o que vossa alteza lá hordena e manda") era enorme. Insistência que reenvia, provavelmente, para a sua pertença à Ordem de Santiago, na qual o primeiro dos valores era, precisamente, o da obediência. ${ }^{71}$

Para além de denotarem uma personalidade reflexiva, essas e outras autorrepresentações parecem cumprir também uma função retórica. Por meio delas, Albuquerque autoriza tanto as suas práticas quanto os conteúdos das suas cartas, o testemunho mais fiável das mesmas.

Que Albuquerque pudesse ser um grande letrado não é, contudo, a qualificação que espontaneamente ocorre para lembrar aquele que foi considerado o César do Oriente, ou, como escreveu Morse Stevens, um novo Alexandre Magno. Até porque ser um grande letrado supunha dominar um corpo de conhecimentos que formatava, necessariamente, a "mundovisão" daquele que o era - e raramente a ação política de Albuquerque foi interpretada tendo em conta essas qualidades. Ao aceitar essa articulação, Albuquerque torna-se um cavaleiro letrado, à maneira do imperador Clarimundo de João de Barros e de

\footnotetext{
${ }^{70}$ Afonso de Albuquerque, "Carta a D. Manuel de 3-12-1513", In: __. Cartas de Afonso de Albuquerque seguidas de documentos que as elucidam, ed. Raymundo António Bulhão Pato, vol. 1, Lisboa, Academia Real das Sciencias de Lisboa, 1884, p. 162. Corroboram essa ideia as muitas referências aos suportes nos quais era registrada a memória burocrática, destacando-se a necessidade de papel de Portugal, que se encontram nas cartas de Albuquerque, preocupações de um oficial atento às solicitações de uma administração letrada. ${ }^{71}$ Afonso de Albuquerque, op cit., p. 187; António Maria Falcão Pestana de Vasconcelos, "A Ordem de Santiago em Portugal nos finais da Idade Média (normativa e prática)," Militarium Ordinum Analecta, n. 2, CEPESE/FEEA, 1999.
} 
alguns discretos do tratado de Castiglione, antecipando D. João de Castro que, décadas mais tarde, encarnou completamente esse modelo.

O universo da sua "criaçam e condiçam", aqui entendidas a partir da sua inscrição familiar, a pertença à Ordem de Santiago e a sua educação na Corte de Afonso V constituem-se como vias de acesso que nos ajudam a resolver esse enigma.

Comece-se pela "condiçam". Sabemos que, pelo lado paterno, Albuquerque pertencia a uma família de oficiais letrados ao serviço da Casa de Avis. O bisavô fora escrivão da puridade de D. João I, participara na conquista de Ceuta, aí tendo sido armado cavaleiro, recebendo depois o título de Senhor de Vila Verde de Francos e de Alenquer. Antes ainda da tomada de Ceuta, Gonçalo Lourenço Gomide recebera uma carta de doação de D. João I que lhe permitia criar "engenhos de fazer ferros, serrar madeira, pisar burel e fazer papel" em Leiria, o que viria a traduzir-se no primeiro moinho de papel de Portugal (o segundo estabelecer-se-ia na Batalha, em 1514, por Manuel de Góis, irmão de Damião de Góis). Sobre o moinho, pouco mais se sabe, mas segundo alguns autores, a sua existência ajuda a explicar o fato de uma das primeiras tipografias portuguesas se localizar naquela cidade. ${ }^{72}$ Além disso, Gonçalo Lourenço de Gomide construiu um panteão familiar na sacristia da igreja da Graça, em Lisboa, segundo Lurdes Rosa, um grande espaço linhagístico que contratara com os frades como local de sepultura sua, da mulher e dos da sua linhagem, claramente com o objetivo de associar à sua condição letrada outro tipo de capital. ${ }^{73}$

Apesar dos grandes prospectos a que Gomide claramente aspirava para a sua linhagem, o seu filho, João Gonçalves Gomide, avô de Albuquerque, perderia o ofício de escrivão da puridade depois de ter assassinado a sua mulher, Leonor de Albuquerque. ${ }^{74}$ A geração de João Gomide passou a ostentar, a partir de então, o apelido da mãe, Albuquerque, e é já com esse apelido que o pai de Afonso de Albuquerque - Gonçalo de Albuquerque — viria a ser conhecido. Terceiro senhor de Vila Verde de Francos (sendo-lhe atribuída a edificação de um paço senhorial nessa vila, no qual Albuquerque terá passado, eventualmente, os seus primeiros anos) Gonçalo de Albuquerque foi, além disso, conselheiro de D. Afonso $\mathrm{V}^{75}$

A mãe de Afonso de Albuquerque era D. Leonor de Menezes, filha do primeiro conde de Atouguia, D. Álvaro Gonçalves de Ataíde. O avô materno também participara na conquista de Ceuta, tendo integrado, em 1416, a embaixada enviada pelo rei ao Concílio de Constança e, em 1429, a embaixada enviada a Castela, visando à conciliação entre D. João II de Castela e os reis de Navarra e Aragão. Governador da casa do infante D. Pedro, D. Álvaro de Atayde fizera-se prender "manhosamente", segundo

\footnotetext{
${ }^{72}$ Ana Maria Leitão Bandeira, Pergaminho e papel em Portugal: tradição e conservação, Lisboa, CELPA Associação da Indústria Papeleira, 1995, p. 59.

${ }^{73}$ Maria de Lurdes Rosa, "As almas herdeiras". Fundação de capelas fúnebres e afirmação da alma como sujeito de direito (Portugal, 1400-1521), Tese de Doutorado, Universidade Nova de Lisboa, Lisboa, 2004, p. 486-487.

${ }^{74}$ Foi, primeiro, apoiante de D. Leonor Teles e, depois, do Mestre de Avis, a quem representou enquanto embaixador de Portugal quando da assinatura do tratado de Windsor. Ver Maria Cristina Fernandes, A Ordem de Santiago no século XIV, Porto, FLUP, 2002, p. 70; 112.

${ }^{75}$ José Manuel Vargas, Aspectos da história de Alhos Vedros (séculos XIV a XVI). Alhos Vedros, Junta de Freguesia de Alhos Vedros, 2007. Recebeu várias doações em 1449, provavelmente como recompensa pelo serviço ao rei na batalha de Alfarrobeira (Humberto Baquero Moreno, $A$ batalha de Alfarrobeira. Antecedentes e significado histórico, vol. II, Coimbra, Biblioteca Geral da Universidade de Coimbra, 1980, p. 690-691).
} 
Ruy de Pina, quando das dissensões entre aquele infante e o sobrinho, D. Afonso V, assumindo o partido do rei, de quem fora aio. ${ }^{76}$ Ataíde casara com D. Guiomar de Castro, aia de D. Leonor (irmã de Afonso V e futura imperatriz da Alemanha), a quem se deve a fundação, em 1455, do importante convento de S. Francisco de Xabregas de Lisboa. Ligada ao reformismo franciscano, D. Guiomar contribuiu, igualmente, para a fundação do convento de S. Francisco de Atouguia da Baleia. ${ }^{77}$

Secundogênito, Afonso de Albuquerque teve como irmão mais velho Fernão de Albuquerque, vedor da casa de D. Jorge, o importante filho bastardo de D. João II e mestre da Ordem de Santiago. Uma das suas irmãs casou com D. Fernando de Noronha, governador da casa da rainha D. Joana, a Excelente Senhora, e alcaidemor de Salir. Filhos desse casamento seriam Garcia de Noronha, futuro vice-rei da Índia, e D. Isabel de Castro (mulher de Pedro Álvares Cabral).

Esses poucos dados já nos permitem refletir sobre a "condiçam" de Afonso de Albuquerque, situando-o tanto no contexto de uma fidalguia que se situou, desde o início da monarquia de Avis, na proximidade do governo régio e no envolvimento nas empresas africanas, ${ }^{78}$ como de uma elite letrada que, desde os inícios da dinastia de Avis, participou na sua burocracia. Ou seja, a biografia de Albuquerque inscrevia-o, simultaneamente, no universo cavaleiresco (daqueles que integravam, nomeadamente, as campanhas africanas) e no universo das letras (daqueles que passavam, tal como Maquiavel, o seu dia-a-dia entre pergaminhos e papéis, entre fórmulas e protocolos de escrita, no bofete entre documentação oficial e oficiosa), ambos profundamente entranhados com os destinos políticos e militares da dinastia de Avis. ${ }^{79}$

Atente-se, agora, na sua "criaçam", quer enquanto cavaleiro da Ordem de Santiago, quer no seu percurso nos paços de D. Afonso V e D. João II.

Sendo escassos os testemunhos encontrados na documentação que persiste nos cartórios da Ordem de Santiago, enquanto seu cavaleiro Albuquerque terá passado pelo menos um ano num dos conventos da Ordem, apesar de poder passar parte desse ano fora, caso para isso tivesse autorização do Mestre. Depois desse ano, teria direito a fazer a profissão, sendo-lhe lançado o hábito e, depois, armado cavaleiro. ${ }^{80}$ Albuquerque terá ainda feito, nessa altura, os três votos de freire-cavaleiro (castidade conjugal, obediência e pobreza),

\footnotetext{
${ }^{76}$ Humberto Baquero Moreno, A batalha de Alfarrobeira. Antecedentes e significado Histórico, vol. II, Coimbra, Biblioteca Geral da Universidade de Coimbra, 1980, p. 723-724.

77Para além da mãe de Afonso de Albuquerque, outros descendentes do casal foram D. Martinho de Ataíde, $2^{\circ}$ conde de Atouguia, D. João de Ataíde e D. Vasco de Ataíde, ambos priores do Crato, tios de Albuquerque e todos muito próximos de D. Afonso V (Paula Pinto Costa, "A ordem militar do Hospital em Portugal", Militarium Ordinum Analecta, n. 3/4, 2000, p. 262-263).

${ }^{78} \mathrm{Em} 1484$, já está inscrito como cavaleiro fidalgo no livro das moradias de D. João Il, por exemplo.

${ }^{79}$ Ver, a esse propósito, José Bono, Historia del derecho notarial español: I, La Edad Media, Madrid, Junta de Decanos de los Colegios Notariales de España, 1979; Guido Van Dievoet, Les coutumier, les styles, les formulaires et les "Artes Notariae", Brepols, Turnhout, 1986; Maria de Lurdes Rosa, "Quadros de organização do poder na Baixa Idade Média. Estrutura familiar, patrimónios e percursos linhagísticos de quatro famílias de Portalegre", A Cidade, n. 4, 1991, p. 47-65.

${ }^{80}$ Afonso de Albuquerque, "Carta ao rei D. Manuel I de 3-12-1513", In: ___ . Cartas de Afonso de Albuquerque seguidas de documentos que as elucidam, ed. Raymundo António Bulhão Pato, vol. 1, Lisboa, Academia Real das Sciencias de Lisboa, 1884, p. 189. Ver António Maria Falcão Pestana Vasconcelos, "A Ordem de Santiago em Portugal nos finais da Idade Média (normativa e prática)", Analecta Ordinum Militaris, n. 2, CEPESE/FEAA, 2000, p. 140-141.
} 
submetendo-se à obrigação do jejum de qualquer outro fiel, usufruindo do direito de testar, bem como de usar, determinadas cores e tecidos, graças à sua condição nobre. Além disso, gozava de privilégios de isenção do foro civil e do foro eclesiástico. ${ }^{81}$

Terá sido como membro da Ordem de Santiago que Albuquerque participou na Batalha de Toro, em 1476 (ao lado de outras figuras como D. Francisco de Almeida, seu futuro rival na Índia), quando tinha cerca de 14 anos, a idade mínima para receber o título de cavaleiro? Ou teria recebido essa distinção quando, em 1480 e 1481, integrou a esquadra enviada em socorro de D. Fernando II de Aragão, visando impedir o avanço dos otomanos no Golfo de Tarento?

Não sabemos, mas para além dos terrenos ibéricos e mediterrânicos, a experiência militar de Afonso de Albuquerque prévia à sua ida ao Índico esteve também associada ao mundo africano, no qual a Ordem de Santiago participou ativamente, sobretudo sob o governo do príncipe D. João - D. João II desde $1481 .^{82}$ Apesar de se supor que terá acompanhado Afonso V nas campanhas de Tânger e de Arzila, onde teria permanecido durante vários anos, não há fontes seguras que o confirmem. Mas sabe-se que comandou a defesa da ilha Graciosa, junto a Larache, em 1489, encontrando-se em Arzila, em 1495, em combates nos quais um dos seus irmãos perderia a vida. ${ }^{83}$

Atendendo às condições que permitiam a sua entrada, bem como o noviciado durante um ano, é mais provável que a sua ordenação como cavaleiro tivesse resultado da primeira viagem ao Índico, da qual regressaria ao reino em 1502, tornando à Índia, com uma capitania-geral, já com o estatuto de cavaleiro da Ordem de Santiago. Uma coisa é certa: pouco antes de 1507, Albuquerque fazia parte de um restrito grupo de 53 cavaleiros e 32 comendadores da Ordem de Santiago (um dos quais era o seu irmão, Fernão de Albuquerque, membro dos “Treze”, ou seja, com importantes funções de governo na Ordem), se deles excluirmos os freires com ordens sacras. ${ }^{84}$

A sua "criaçam" como cavaleiro da Ordem de Santiago é já posterior, porém, à sua "criaçam" na Corte de Afonso V. À semelhança de outros filhos de oficiais da Corte afonsina - caso de António Carneiro, de Duarte Galvão e de Martinho Castelo Branco, três das suas amizades mais consistentes e duradouras, vindo Duarte Galvão a casar, até, com a sua prima Isabel de Albuquerque -,

\footnotetext{
${ }^{81}$ Carlos Fernando Russo Santos, Pe., A Ordem de Santiago e o papado no tempo de D. Jorge. De Inocêncio VIII a Paulo III, Porto, FLUP, 2004, p. 42 et seq; António Maria Falcão Pestana Vasconcelos, "A Ordem de Santiago em Portugal nos finais da Idade Média (normativa e prática)", Analecta Ordinum Militaris, n. 2 , CEPESE/FEAA, p. 124

${ }^{82}$ Anselmo Braancamp Freire, "A Guarda de D. João II no ano de 1490", Archivo Historico Portuguez, vol. 5, 1903-1917, p. 345-366.

${ }^{83} \mathrm{Em}$ 1490, fazia parte da guarda de D. João II, sob o comando de Fernão Martins de Mascarenhas; esse período africano foi mediado por uma estadia no reino (Anselmo Braancamp Freire, op cit.)

${ }^{84}$ Fernão de Albuquerque seria também vedor da Casa de D. Jorge, comendador da Horta Lagoa, pertencendo ao grupo dos Treze em 1508 (Maria Cristina Pimenta, "As Ordens de Avis e de Santiago na Baixa Idade Média", Militarium Ordinum Analecta, n. 5, 2001, p. 179; 405; Francis A. Dutra, "New knights in the Portuguese order of Santiago during the Mastership of D. Jorge, 1492-1550", Humanista, vol. 2, 2002, appendix, p. 113; 115. António M. F. P. Vasconcelos refere ser 1503 o ano de entrada (Nobreza e Ordens Militares, vol. 2, Porto, FLUP, p. 117). Note-se que, entre os que receberam a Ordem de Santiago, encontravam-se nada menos do que Gregório Lopes e o seu filho Cristóvão Lopes, dois dos principais pintores da Corte portuguesa de Quinhentos e representantes da classicização, pela pintura, da mesma.
} 
Afonso de Albuquerque recebeu uma bolsa régia para ser educado no paço. ${ }^{85}$ Mediante os trabalhos de Rita Costa Gomes e de Saúl Gomes, sabe-se que esses meninos aprendiam a desempenhar uma série de funções, assistindo à capela, à câmara, à repostaria, à copa, à caça, à montaria e estrebaria, recebendo, ao mesmo tempo, uma educação letrada ministrada por mestres comuns. ${ }^{86} \mathrm{O}$ bacharel Pedro Álvares, o mestre de gramática Afonso Rodrigues, ou o cônego lóio João Rodrigues poderão ter sido alguns dos seus mestres. ${ }^{87}$ É possível, ainda, que Albuquerque circulasse em torno do infante D. João, futuro D. João II, sobre cuja educação os dados também são escassos, apesar dos aplausos que Münzer e Cataldo lhe fazem, ${ }^{88}$ e das referências de Garcia Resende ao gosto que o futuro rei tinha em "disputas de grandes teólogos e letrados".89

Em todo o caso, a informação sobre os conteúdos da educação nos paços reais dos Avis continua a ser incompleta. Maria Helena da Cruz Coelho definiu os príncipes de Avis como "homens cultos e de sólida formação literária", adeptos da literatura religiosa, dos romances de cavalaria, das narrativas do amor cortês e promotores da leitura e tradução dos "clássicos" em vernáculo, reiterando uma imagem relativamente consensual que paira sobre a geração de Avis. ${ }^{90}$ Sabemos que tanto D. João I quanto D. Duarte e o infante D. Pedro escreveram tratados relacionados com o governo de si e o governo da república, neles convocando quer a teologia moral, quer os saberes clássicos, e que um tratado sobre cavalaria, entretanto desaparecido, é atribuído ao próprio D. Afonso $\mathrm{V}^{91}$

Afonso V tinha, segundo Ruy de Pina, "por mui familiares os livros, principalmente aquelles, em que os virtuosos costumes e claros feitos dos illustres Reis e Principes passados fossem verdadeiramente escriptos". Além disso, "como mui prudente, sabia que os livros, posto que sejam conselheiros mortos, sempre porém ensinam e dão verdadeiros e sãos conselhos, mui livres e isentos das paixões dos conselheiros vivos".92 Sabemos ainda que Afonso V mandou edificar, entre 1450 e 1451, a primeira biblioteca real, inspirada na dos reis de Aragão, a qual não só reunia as bibliotecas de D. João I e de D. Duarte (e o seu "Leal Conselheiro", evidentemente), como também continha os tratados do infante D. Pedro e suas

\footnotetext{
${ }^{85} \mathrm{Um}$ rol de 1473 indica vários tipos de bolsas, de 7 a 8 mil reais para os filhos de fidalgos de maior importância e de 5 a 6 mil reais para os que se seguiram, entre os quais, filhos da toga e de nobreza mediana (Saúl Gomes, Afonso V, Lisboa, Círculo de Leitores, 2006, p. 164). Ver, a esse propósito, Humberto Baquero Moreno, "Um aspecto da política cultural de D. Afonso V: a concessão de bolsas de estudo", Revista das Ciências do Homem, série A, n. 3, 1970, p. 177-205.

${ }^{86}$ Rita Costa Gomes, A corte dos reis de Portugal no final da Idade Média, Lisboa, Difel, 1995; Saúl Gomes, op cit. ${ }^{87}$ Saúl Gomes, op cit., p. 59.

${ }^{88}$ Luís Adão da Fonseca, D. João II, Lisboa, Círculo de Leitores, 2005, p. 187 et seq.

89/bidem, p. 193

${ }^{90}$ Maria Helena da Cruz Coelho, D. João I, Lisboa, Círculo de Leitores, 2005, p. 258 et seq; João Gouveia Monteiro, "Orientações da cultura de corte na 1 a metade do século XV (a literatura dos príncipes de Avis)", Vértice, 2a série, n. 5, 1988, p. 89-103; Augusto Aires de Nascimento, "As livrarias dos príncipes de Avis", Biblos, vol. LXIX, 1993, p. 265-287; e, ainda, Maria Helena da Cruz Coelho, "Les relations du savoir et du pouvoir dans le Portugal médiéval (XIVe et XVe siècles)", In: Raphaela Averkom et al. (orgs.), Europa und die Welt in der Geschichte. Festschrift für Dieter Berg zu seinem 60. Geburtstag, Bochum, Dieter Winckler, 2004, p. 313-334. ${ }^{9}$ Segundo António de Caetano e Sousa, também a infanta D. Filipa, filha de D. Pedro, teria sido autora de várias obras (António de Caetano e Sousa, História genealógica da Casa Real portuguesa, vol. II, Coimbra, Atlântida, 1946, p. 47).

${ }^{92}$ Rui de Pina, Chronica de D. Afonso V, tomo 1, Lisboa, Escriptório, 1901-1902, Prólogo.
} 
traduções - caso do De officis, de Cícero, e supostamente do Epitoma rei militari, de Vegecio, livro já citado nos tratados de D. Duarte e também referenciado por Zurara - ${ }^{93}$ os tratados que são atribuídos a Afonso V (entretanto desaparecidos), bem como obras de Sêneca, a Vida, de Júlio César e os seus Commentarios, os Pharsalia, de Lucano, as Décadas, de Tito Lívio, a Vida de Alexandre. ${ }^{94}$ Alguns desses livros foram adquiridos, precisamente, na Florença dos Médicis, cidade com a qual a Corte de Afonso V mantinha importantes relações. ${ }^{95}$

Além disso, tanto no reinado de D. Afonso V quanto no de D. João II, a circulação de escolares entre Portugal e Itália ${ }^{96}$ e de humanistas em sentido inverso é grande, apontando-se a data da chegada de Cataldo Sículo, em 1485, mestre de D. Jorge e secretário de D. João II, como o início formal do humanismo português. Antes disso, porém, homens como Vasco Fernandes de Lucena ostentavam todas as insígnias do humanismo, envolvendo-se quer nas orações laudatórias, quer na tradução de livros do latim para o português. ${ }^{97}$

A paixão que o monarca teria pelos livros úteis convida a pensar, pois, que a educação dos jovens criados na Corte tivesse uma explícita dimensão livresca. Teria Albuquerque entrado em contato com alguns desses livros e com as ideias de virtus que eles veiculavam? Certamente. Geneviéve Bouchon coloca a hipótese, aliás, de Albuquerque ter ouvido as proezas de Alexandre e de César por meio do seu contato com mestres italianos, deixando nas entrelinhas ser esse o modelo que alimentava a sua ação. Também António Baião defendeu a educação latina, de humanista, de Albuquerque, no contexto da qual teria lido as histórias de Alexandre Magno (mas também d'El Cid).$^{98}$ A favor dessas hipóteses, está uma referência que consta dos Commentarios escritos por Brás de Albuquerque, que relata um encontro entre Albuquerque e um muçulmano, no qual o segundo dizia que lera a vida de Alexandre, ao que Albuquerque lhe respondera que ele também o lera e lhe era muito afeiçoado! ${ }^{99}$

Em suma, é bastante provável que a leitura dos "clássicos" tenha integrado a "criação" de Albuquerque nas Cortes afonsina e joanina, temperada com a sua experiência nos palcos tradicionais da guerra - a península ibérica, o Mediterrâneo e o norte da África. Ao contrário de Maquiavel, desde cedo a

\footnotetext{
${ }^{93}$ Vegecio, Compendio de Arte Militar, ed. de João Gouveia Monteiro e José Eduardo Braga, Coimbra, Imprensa da Universidade de Coimbra, 2004, p. 139.

${ }^{94}$ Também na livraria do mosteiro da Batalha havia várias obras italianas, entre as quais Lorenzo Valla, Giovanni Pontano etc.; e o mesmo acontecia na livraria do convento de São Francisco de Leiria, que recebera como doação a biblioteca do infante D. Fernando, irmão de Afonso V (Saúl Gomes, Afonso V, Lisboa, Círculo de Leitores, 2006, p. 157; Augusto Aires de Nascimento, “As livrarias dos príncipes de Avis", Biblos, vol. LXIX, 1993, p. 265-287).

${ }^{95} \mathrm{Ver}$, a esse propósito, Albinia de la Mare, "Notes on the Portuguese Patrons of the Florentine book trade of the $15^{\text {th }}$ century", bem como Kate Lowe, "Rainha D. Leonor of Portugal's patronage in Renaissance Florence and cultural exchange", In: Kate Lowe (org.), Cultural links between Portugal and Italy in the Renaissance, New York, Oxford University Press, 2000.

${ }^{96}$ António Domingues de Sousa Costa, Portugueses no Colégio de S. Clemente e Universidade de Bolonha durante o século XV. Bologna, Real Colégio de España, 1990. 2 v.

${ }^{97}$ Américo da Costa Ramalho, Para a história do humanismo em Portugal, Lisboa, Imprensa Nacional, 19882000. 4 V.

${ }^{98}$ António Baião, Afonso de Albuquerque, Lisboa, Livraria Ferin, 1913, cap. 2; Geneviéve Bouchon, Albuquerque: leão dos mares da Ásia, Lisboa, Quetzal, 2000, p. 21.

${ }^{99}$ Brás de Albuquerque, Commentarios do grande Afonso de Albuquerque, tomo 1, Lisboa, Joam Barreyra, 1557, cap. XXVII.
} 
experiência militar ultramarina e a guerra marítima fizeram parte da sua formação militar, enquanto o florentino tinha mais conhecimento da guerra territorial. À semelhança de Maquiavel, muito embora em tarefas bem distintas (já que Albuquerque esteve sempre associado à carreira militar), a vida cortesã também fez parte da sua experiência. Os exemplos dos heróis militares terão servido de modelo concreto para a sua ação no Índico, diferentemente do florentino, que os utiliza na reflexão escrita. ${ }^{100}$ Não tenho dúvidas de que Albuquerque procurou inscrever a sua biografia numa genealogia de heróis clássicos, como César e Alexandre, e medievais, como El Cid e Nuno Álvares Pereira. Como recentemente argumentou Vincent Barletta, a figura de Alexandre era evocada na cronística portuguesa desde o início de Quatrocentos. Por outro lado, o culto dos heróis recentes - dentre os quais se destacava também o infante D. Fernando era favorecido. ${ }^{101}$ Essa memória está bem presente, aliás, numa missiva para Duarte Galvão (algures depois da conquista de Malaca), na qual Albuquerque compara o modo como se estimava o valor e a honra no século precedente e na época em que vivia, considerando que seria muito difícil a Nuno Álvares, caso fosse seu contemporâneo, estabelecer uma nova linhagem e uma casa com tal estado!102

\section{A paixão que o monarca teria pelos livros úteis convida a pensar, pois, que aeducação dos jovens criados na Corte tivesse uma explícita dimensão livresca}

Pensava-se em Albuquerque também como um Nuno Álvares do Índico? Possivelmente. Mas além da intencionalidade mimética, a construção de Albuquerque dependeu, ainda, dessa combinatória entre recursos da memória e do entendimento e das evocações que situações concretas despoletavam. Tal como em Maquiavel, Albuquerque foi muito sensível à circunstância.

\section{Conclusão}

É tempo de regressar, agora, às questões iniciais. No que diz respeito a saber se existem conexões entre o pensamento político de Afonso de Albuquerque e o de Maquiavel relativamente aos temas da conquista e da conservação de territórios, creio poder responder afirmativamente. Depois do que ficou exposto, torna-se evidente que, apesar de não se verificar uma sintonia total entre os

\footnotetext{
${ }^{100}$ Sabe-se que esses modelos não só circulavam, mas que os reis de Portugal se associavam publicamente a eles. E não é por acaso, certamente, que pouco antes de Albuquerque conquistar Ormuz, o seu companheiro de armas Tristão da Cunha protagonizaria, em Roma, uma magnífica entrada alla romana.

${ }^{101}$ Maria de Lurdes Rosa, "Do 'santo conde' ao mourisco mártir: usos da santidade religiosa no contexto da guerra norte-africana (1415-1521)", In: Michael Kraus; Hand Ottermeyer (orgs.), Neue Welten. Portugal und das Zeitalter der Entdeckungen, Berlin, Deutsches Historisches Museum, 2007.

${ }^{102}$ Afonso de Albuquerque, "Carta a Duarte Galvão", In:___. Cartas de Afonso de Albuquerque seguidas de documentos que as elucidam, ed. Raymundo António Bulhão Pato, vol. 1, Lisboa, Academia Real das Sciencias de Lisboa, 1884, p. 395 et seq.
} 
dois - e de, sobretudo, haver fortes divergências relativamente às formas de operacionalização da conquista, caso do papel dos mercenários e das fortalezas -, há um conjunto de matérias nas quais o pensamento de Albuquerque e de Maquiavel vai numa mesma direção.

A questão da força - e da reputação do príncipe associada às suas manifestações e à percepção que dela os outros tinham —é, evidentemente, central. Mas também são interessantes temas como a liga das cidades (o modelo inicialmente aplicado por Albuquerque à conquista e à conservação da Índia), ou a conservação dos territórios a partir de colônias de colonos, a quem se distribuiriam casas e terras.

Questiona-se se essas sintonias revelam a existência de um lastro cultural mediterrânico na cultura política de Quinhentos - de raiz cristã e humanista, com aspirações imperialistas onipresentes, abrangendo Florença (Itália) e Portugal — e do qual podiam resultar soluções semelhantes. Apesar de ser uma hipótese ainda radicada em muita incerteza - ainda que já não sejam irrelevantes os estudos que exploram as relações entre esses dois mundos —,${ }^{103}$ creio poder responder afirmativamente também a essa questão. De fato, os estudos mais recentes sobre a história cultural portuguesa de Quatrocentos — na sequência, aliás, de trabalhos anteriores, nomeadamente sobre o humanismo português - têm dado conta das fortes conexões entre o mundo português e italiano e, em concreto, entre a Corte portuguesa e a Corte florentina. Mais trabalhos nessa área são necessários para que a hipótese aqui enunciada se confirme plenamente, mas é provável que, sob muitos aspectos, a formação livresca de Albuquerque não fosse muito diferente daquela de florentinos de geração e condição equivalente.

A terceira questão que coloquei no início - a de saber se podemos pensar que, à semelhança de Maquiavel, a estratégia e as táticas adotadas por Albuquerque nas conquistas no Índico resultaram da combinação entre a sua experiência política e militar e da influência que a leitura dos clássicos romanos nele poderá ter exercido - está de algum modo associada à questão anterior. Sabemos hoje que as bibliotecas dos Avis estavam recheadas de leituras clássicas, entre as quais a Vida de Alexandre, os Comentários de Júlio César, as Décadas de Tito Lívio e o Epitoma de re militarii de Vegecio. Este último, por exemplo, fazia parte da formação de qualquer cavaleiro europeu, pertencendo "à bagagem intelectual dos chefes de guerra ocidentais", pelo que direta ou indiretamente Albuquerque teria tido conhecimento dos seus preceitos. Foi a Vegecio, bem como a Leonardo Bruni, que bebe daquele, que Maquiavel se inspirou para desenvolver as suas teses contra os mercenários. ${ }^{104}$ É possível que Albuquerque tenha ido buscar saberes sobre a guerra marítima também no Epitoma de Vegecio, selecionando desse tratado aquilo que lhe era mais útil. Algo semelhante pode ter acontecido na recepção das Décadas de Tito Livio, tão inspiradoras de Maquiavel, as quais se constituíam como uma verdadeira enciclopédia sobre a glória dos romanos e uma leitura incontornável das elites portuguesas de Quinhentos.

\footnotetext{
${ }^{103}$ Artur Moreira de Sá, Humanistas portugueses em Itália. Subsídios para o estudo de Frei Gomes de Lisboa, dos dois Luíses Teixeiras, de João de Barros e de Henrique Caiado, Lisboa, Imprensa Nacional; Casa da Moeda, 1983. ${ }^{104}$ Vegecio, Compendio de arte militar. Edição de João Gouveia Monteiro e José Eduardo Braga, Coimbra, Imprensa da Universidade de Coimbra, 2004, p. 126; 130.
} 


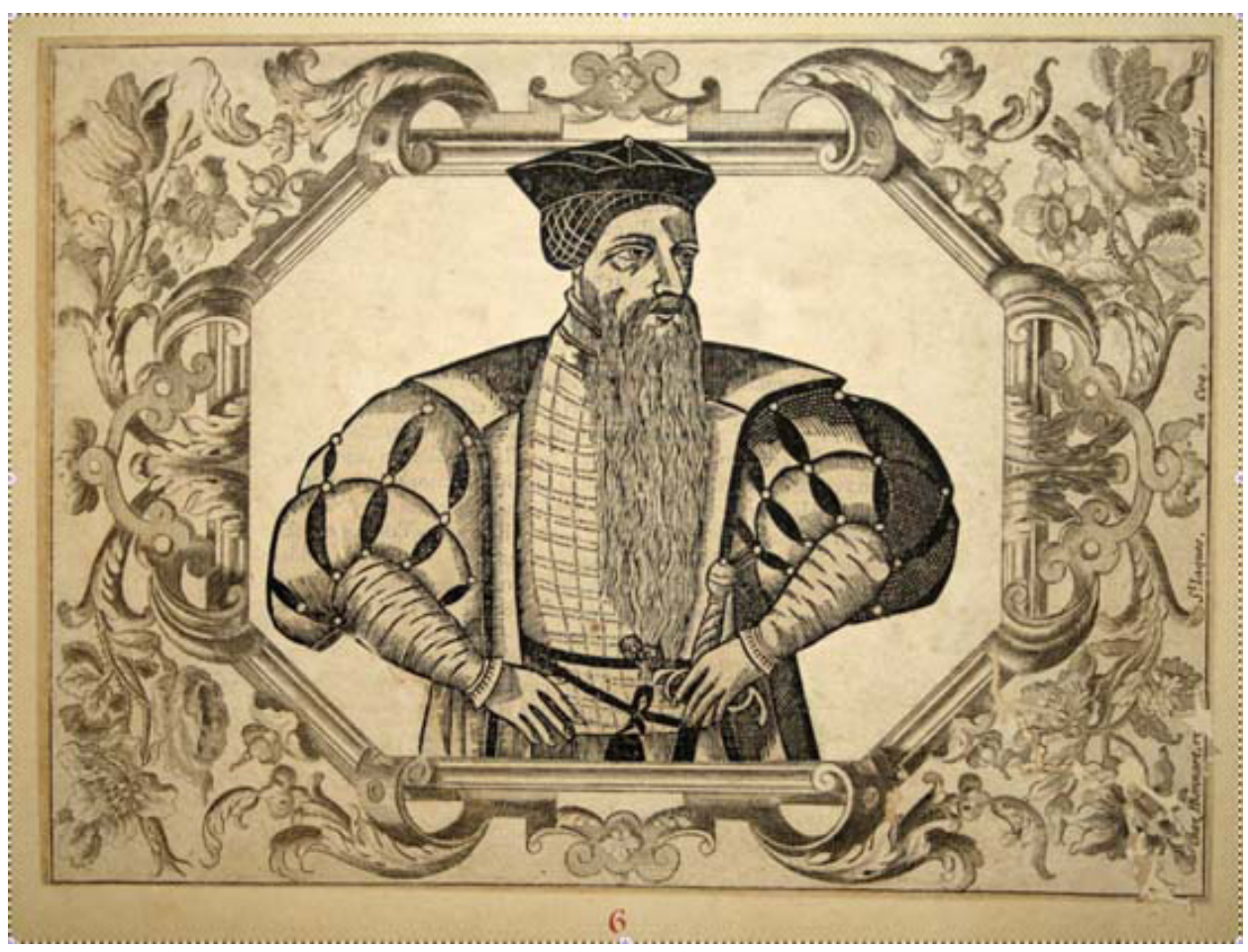

Figura. Imagem de Afonso de Albuquerque proveniente da coleção de retratos compilados por Diogo Barbosa Machado (1682-1772). A figura recortada, de autoria anônima, foi gravada a buril e retirada de uma edição do livro Ásia portuguesa, de Manuel de Faria e Sousa. Ela teria sido feita com base no original existente na galeria dos vice-reis e governadores de Goa, iniciada por D. João de Castro, na qual o poder portuquês na região é teatralizado, com claras intenções políticas. É de salientar a representação esteticamente híbrida da personagem, combinando elementos de origens portuguesa e asiática, o que era frequente nas produções a partir da Corte de Goa. À semelhança deste, também outros retratos da galeria dos vice-reis denotam um gosto indianizado. Manuel de Faria y Sousa, Ásia portuquesa, tomo I, Lisboa, Officina de Henrique Valente de Oliveira, 1666, p. 171 e Diogo Barbosa Machado (org.), Retratos de varões insignes em campanha e gabinete, tomo VI, [Lisboa] s. n. t., Rio de Janeiro, Biblioteca Nacional do Brasil, seção de iconografia. 